\title{
MICROSPHERES AS INTRAOCULAR THERAPEUTIC TOOLS IN CHRONIC DISEASES OF THE OPTIC NERVE AND RETINA
}

Irene Bravo-Osuna, Vanessa Andrés-Guerrero, Alicia Arranz-Romera, Sergio EstebanPérez, Irene T Molina-Martínez, Rocío Herrero-Vanrell*

Department of Pharmacy and Pharmaceutical Technology, School of Pharmacy, Complutense University of Madrid, Spain.

Sanitary Research Institute of the San Carlos Clinical Hospital (IdISSC), Madrid, Spain. Ocular Pathology National Net (OFTARED) of the Institute of Health Carlos III, Spain. Instituto Universitario de Farmacia Industrial (IUFI). School of Pharmacy, Complutense University of Madrid, Spain.

ACKNOWLEDGMENTS- ISCIII-FEDER Red Temática de Investigación Cooperativa en Oftalmología RETICS (Oftared) RD12/0034/0003 and RD12/0034/0014, Complutense Research Group UCM 920415-GR3/14, Spanish Ministry of Economy and Competitiveness MICINN-MAT 2013-43127R and Spanish Ministry of Health and Consumption. Spanish Fund for Health Research FIS PI12/02285.

* Corresponding author. Phone number: +34 913941 39. Fax number: +34 913941 736; e-mail address: rociohv@ucm.es 


\section{ABSTRACT}

Pathologies affecting the optic nerve and the retina are one of the major causes of blindness. These diseases include age-related macular degeneration (AMD), diabetic Retinopathy (DR) and glaucoma, among others. Also, there are genetic disorders that affect the retina causing visual impairment. The prevalence of neurodegenerative diseases of the posterior segment are increased as most of them are related with the elderly. Even with the access to different treatments, there are some challenges in managing patients suffering retinal diseases. One of them is the need for frequent interventions. Also, an unpredictable response to therapy has suggested that different pathways may be playing a role in the development of these diseases. The management of these pathologies requires the development of controlled drug delivery systems able to slow the progression of the disease without the need of frequent invasive interventions, typically related with endophthalmitis, retinal detachment, ocular hypertension, cataract, inflammation, and floaters, among other. Biodegradable microspheres are able to encapsulate low molecular weight substances and large molecules such as biotechnological products. Over the last years, a large variety of active substances has been encapsulated in microspheres with the intention of providing neuroprotection of the optic nerve and the retina.

The purpose of the present review is to describe the use of microspheres in chronic neurodegenerative diseases affecting the retina and the optic nerve. The advantage of microencapsulation of low molecular weight drugs as well as therapeutic peptides and proteins to be used as neuroprotective strategy is discussed. Also, a new use of the microspheres in the development of animal models of neurodegeneration of the posterior segment is described.

KEYWORDS: Microspheres, Protein release, Age-Related-Macular Degeneration (AMD); Glaucoma; Diabetic Retinopathy (RD); Neuroprotection; Animal models; Peptides reléase. 


\section{ABBREVIATIONS}

Age-related macular degeneration (AMD)

Arising retinal pigment epithelial cells (ARPE)

Basic fibroblast growth factor (b-FGF)

Bovine serum albumin (BSA)

Brain-derived neurotrophic factor (BDNF)

Central nervous system (CNS)

Ciliary neurotrophic factor $(\mathrm{CNTF})$

Circular dichroism (CD)

Corneal neovascularization (CNV)

Cyclooxigenase (COX)

Diabetic retinopathy (DR)

Diethylamine-azobenzene-quaternary ammonium (DENAQ)

Electroretinography (ERG)

Enzyme-Linked ImmunoSorbent Assay (ELISA)

Erythropoietin (EPO)

Glial cell-line derived neurotrophic factor (GDNF)

GDNF family ligands (GFLs)

Human Umbilical Vein Endothelial Cells (HUVECs)

Inner Nuclear Layer (INL)

Inner plexiform layer (IPL)

Intraocular drug delivery system (IDDS)

Intraocular pressure (IOP)

Matrix metalloproteinase 2 (MMP-2)

Microspheres (MS)

Nonsteroidal anti-inflammatory drugs (NSAIDs)

Outer Nuclear Layer (ONL)

Phosphate-buffered saline (PBS)

Poly (lactic-co-glycolic) acid (PLGA)

Poly (ester amide)s (PEAs)

Poly (lactic) acid (PLA)

Poly-beta amino ester (PBAE)

Polyethylene glycol (PEG) 
Quaternary ammonium-azobenzene-quaternary ammonium (QAQ)

Radial peripapillary capillaries (RPCs)

Retinal ganglion cells (RGCs)

Retinal pigment epithelial cells (RPE)

Retinitis pigmentosa (RP)

Rod-phosphodiesterase (PDE)

rod-phosphodiesterase (PDE)

size-exclusion chromatography (SEC)

Sodium dodecyl sulfate- Polyacrylamide gel electrophoresis (SDS-PAGE)

Terminal deoxynucleotidyl transferase dUTP nick end labeling (TUNEL)

Transforming growth factor- $\beta$ (TGF- $\beta$ )

Triamcinolone acetonide (TA)

US Food and Drug Administration (FDA)

Vascular endothelial growth factor (VEGF)

Vitamin E (Vit E)

\section{1.- INTRODUCTION:}

Pathologies affecting the optic nerve and retina are one of the major causes of blindness. These diseases include age-related macular degeneration (AMD), diabetic retinopathy (DR) and glaucoma, among others (1-3). The prevalence of neurodegenerative diseases of the posterior segment has increased as most of them are related with the elderly (4). Also, there are genetic disorders that affect the retina causing visual impairment such as retinitis pigmentosa, Leber's congenital amaurosis, Startgaard disease and choroideremia, among others.

There are several clinical issues related to the management of neurodegenerative diseases affecting the retina or surrounding tissues. This is the case of neovascular age related macular degeneration and proliferative retinopathy patients affected that need frequent intravitreal injections of anti-VEGF agents. Also, it is important to notice the poor compliance in the treatment with antihypertensive drugs in glaucoma patients with high intraocular pressure (IOP) values. Neurodegeneration is other important issue as it is 
present in glaucoma patients with high IOP values with no response to hypotensive therapy and in normotensive subjects.

Delivery of active substances in therapeutic concentrations to the targeted intraocular tissues is restricted by the effective static (corneal layers, sclera, retina, blood aqueous and blood retinal barriers) and dynamic barriers (tear dilution, conjunctival and choroidal blood flow, and lymphatic clearance) as well as efflux pumps that are present in the eye (5) (fig 1). Instilled drugs have poor bioavailability in the intraocular tissues (6). For this reason, the ophthalmic topical administration is restricted to the treatment of pathologies involving the ocular surface or whether the pharmacological target is located in the anterior segment of the eye. Intraocular and periocular injections are used to release therapeutic molecules inside the eye. In the case of intravitreal injections the drug is injected close to the retinal tissues, which leads to the highest biovailability in the posterior segment tissues compared with the other local routes of administration. Although periocular injections are less invasive, the therapeutic molecule has to reach the posterior segment by diffusion through different tissues.

Intravitreal injections are regularly used in the clinical practice for the treatment of posterior segment diseases. However, even with the available access to different ocular therapies, there are some challenges in the management of patients suffering retinal diseases. One of them is the need of frequent interventions. Also, an unpredictable response to therapy has suggested that different pathways may be playing a role in the development of these diseases. This might the reason why monotherapy is not enough to slow the progression of the degeneration (7).

One of the most challenging areas in ophthalmology therapy is dedicated to decrease the number of interventions. Under the technological point of view this objective can be achieved thanks to the development of intraocular drug delivery systems (IDDS) (8). These devices are prepared with different biomaterials to provide sustained delivery of the active molecule close to the target site during long term. Depending on the properties of the biomaterial the IDDS can disappear from the site of administration (biodegradable) or remain during the lifetime of patients (non-biodegradable).

According to their size, IDDS are classified as implants (size > $1 \mathrm{~mm}$ ), microparticles (size $1-1000 \mu \mathrm{m})$ or nanoparticles $(1-1000 \mathrm{~nm})$. The different drug delivery systems are useful for the treatment of neurodegenerative diseases affecting the posterior segment of the eye. 
The right choice of the most adequate IDDS depends on the target site, the ophthalmic disease and the duration of the treatment. While implants and microparticles deliver the drug for long periods of time, nanoparticles have the advantage to be internalised by cells being useful for gene therapy $(9,10)$.

Implants are currently used in the clinical practice to provide long term delivery of therapeutic molecules. Several non-biodegradable (Vitrasert ${ }^{\mathrm{TM}}$, $\operatorname{Retisert}^{\mathrm{TM}}$ and Medidur $^{\mathrm{TM}}$ ) and one biodegradable $\left(\right.$ Ozurdex $\left.{ }^{\circledR}\right)$ macrodevices are commercialised (8).

Microparticulate systems are able to encapsulate and deliver the drug for several months. Attending to their structure, they received the name of microcapsules if the drug is surrounded by a polymer or polymer mixture (reservoir) and microspheres if the drug is dispersed in the polymer network (matrix). Injection of microparticles can be performed by using small gauge needles (25-32G). Personalised therapy is possible as different drug doses are administered depending on the amount of administered microparticles. Biodegradable microparticles are preferred as they gradually disappear from the site of administration (5).

Biodegradable polymers (gelatin, albumin, polyorthoesters, polyanhydrides and polyesters) have been explored to prepare microspheres for intraocular administration. Among them, the poly(lactic) acid (PLA), poly(glycolic) (PGA) and their co-polymers poly(lactic-co-glycolic) acid (PLGA) are the most employed as they are approved for clinical purposes. The use of injectable microspheres has become more popular over the last few decades (5). Typical patterns of in vitro drug release from PLGA microspheres is presented in fig 2. As example of degradation behaviour, a schematic representation of PLGA microspheres evolution on release media is also included.

The main objective of the design of microparticulate drug delivery systems has been to obtain long-acting injectable drug depot formulations. Biodegradable microspheres are able to encapsulate low molecular weight substances and large molecules such as biotechnological products. Over the last years, a large variety of active substances has been encapsulated in microspheres with the intention of providing neuroprotection of the optic nerve and retina. 
The purpose of the present review is to describe the use of microspheres in neurodegenerative diseases affecting the retina and the optic nerve. Also, a new use of the microspheres in developing animal models is discussed.

\section{2.- CHRONIC DISEASES OF THE OPTIC NERVE AND RETINA}

Advances in the understanding of pathogenesis that lead to retinal cell death have been essential to gain new insights about neurodegenerative diseases like age-related macular degeneration, diabetic retinopathy or glaucoma. These pathologies share a common pathophysiologic pathway that includes oxidative stress, axonal transport impairment, neuroinflammation, and excitotoxicity, which are the major cause of retinal cell death.

\subsection{Age-related macular degeneration}

Age-related macular degeneration (AMD) accounts for $8.7 \%$ of all blindness worldwide and is the most common cause in developed countries, especially in people older than 60 years (11). This pathology is becoming more prevalent in the developing world due to an exponential population ageing. Differences in prevalence from diverse populations may offer insights into possible environmental and genetic causes of AMD (12). Environmental and behavioral factors for AMD include cigarette smoking, obesity, low dietary intake of vitamins $\mathrm{A}, \mathrm{C}$ and $\mathrm{E}$, zinc, lutein and omega-3 fatty acids, and an unhealthy lifestyle related to cardiovascular risk factors (13).

AMD is characterized by a central vision loss due to degenerative alteration in the macular region of the retina (fig 3). The disease can be classified as dry or wet AMD, depending on the absence or presence of choroidal neovascularization, respectively. In wet AMD, the growth of new blood vessels from the choroid into the sub-retinal space and sub-retinal pigment epithelium is responsible for the vision loss (13). In addition, in both dry and wet AMD, the pathology manifests as pigmentary irregularities of the retina and deposits called drusen, which are accumulations of extracellular material immediately beneath the retinal pigment epithelium. Although drusen are a manifestation of the normal ageing process, they can represent an important sign associated with retinal disease (14). Patients usually develop rapid visual loss when neovascular AMD occurs. Typically, they describe sudden worsening of central vision with distortion of straight 
lines, a dark patch in their central vision, or both. Treatment of wet AMD includes laser photocoagulation, photodynamic therapy, anti-VEGF therapy and visual rehabilitation.

Laser photocoagulation is effective in reducing long-term severe visual loss, but is limited by lack of vision gain and high recurrence rates $(50 \%)$, and a risk of immediate moderate visual loss (41\%) (15). Photodynamic therapy consists of a two-stage process involving intravenous infusion of verteporfin, a green photosensitizing dye that accumulates preferentially in neovascular membranes, followed by a dye activation with infrared light (16). This process generates oxygen-free radicals that damage the endothelium, promoting closure of newly formed vessels. This therapy is not exempt from adverse events that include photosentivitity, headaches, acute severe visual loss (in $4 \%$ of patients), and chorioretinal atrophy able to lead to gradual visual deterioration (17).

Progress in understanding the key role of vascular endothelial growth factor (VEGF) in choroidal neovascularization has led to the development of molecules that by blocking VEGF are able to partly revert some of the pathological mechanisms shown in neovascular AMD. Anti-VEGF drugs are typically administered by intravitreal injection, and include pegaptanib, ranibizumab, bevacizumab and aflibercept (18-24).

\section{2.- Diabetic retinopathy}

Diabetic retinopathy (DR) is a leading global cause of vision-loss. In 2010, it was estimated that around one third of 285 million people with diabetes mellitus worldwide had signs of DR (25). In approximately one third of people with DR, the pathology was vision-threatening, defined as severe retinopathy or macular edema (26). For progression of vision loss, the most clinically important risk factors are duration of diabetes, hyperglycemia and hypertension. Emerging evidence supports a genetic component for DR, showing a heritable tendency independent of shared risk factors (27-29).

On the early stages of diabetic retinopathy, localized dilatations of the eye microvasculature appear in patients, which are assumed to be related with weaknesses in the vessel wall, pressure disturbances, or glial retraction/death (30). An increment in the appearance or disappearance of these microaneurysms has been found to be related with the progression of retinopathy and also with eventual visual function decrements (31). 
Other lesions in early stages of the pathology, which are also important in the eventual progression to neovascularization, include capillary non-perfusion and degeneration (32, 33). Both stimulate the release of hypoxia-regulated vasoproliferative factors, such as VEGF, correlated with an increase in neovascularization and vascular leakage. In advanced stages of DR, mechanisms of DR-related vision loss include vitreous hemorrhage, tractional retinal detachment from proliferative $\mathrm{DR}$, development of a fibrovascular membrane in the vitreous, and macular edema (34) (fig. 4).

To inhibit the development or progression of DR, several approaches are currently used in the clinical practice. In early stages of the pathology, interventions are directed towards control of blood pressure, hyperglycemia, and lipids. However, maintaining these parameters under control is challenging in many diabetic patients (35-38). In advanced stages of DR, treatments include pan-retinal laser photocoagulation, or intravitreal injections of anti-VEGF agents and steroids. Laser can largely control neovascularization and prevent blindness, however this treatment cannot restore vision, and, as mentioned before, it has vision-impairing effects of its own as well (39). Regarding the use of antiVEGF or steroids, they can significantly reduce macular edema (40, 41). Unfortunately, their beneficial effects have been found to be temporary in comparison with the effects of standard photocoagulation, and they are also associated with vision-threatening complications related to repeated intravitreal injection (41). Hence, given the limitations of these therapies, vision loss from DM is a significant healthcare concern (42).

\section{3.- Retinitis pigmentosa}

Retinitis pigmentosa (RP) refers to a group of inherited dystrophies characterized by progressive degeneration of the visual cells and abnormalities in retinal pigment epithelium, with an outcome of blindness typically achieved after several decades, during which vision is slowly and irreversibly lost (43). The prevalence of RP is 1:3000 to 1:7000. More than 3000 mutations in over 57 different genes and 61 loci are currently known to cause the non-syndromic form of RP (www.orpha.net).

Night blindness, due impairment of rod photoreceptors, is the first manifestation of the disease and it typically manifests during early adolescence. Then, a progressive death of these cells is produced and, as a consequence, patients experience alterations of the visual 
field. At the beginning, loss of rods is produced in the peripheral retina generating "tunnel vision" (fig. 5). Later, patients undergo a progressive deterioration of visual acuity in the central field as well as a decline of chromatic discrimination, due to the gradual cones death, which leads RP patients to a condition of legal blindness (44).

Degeneration mechanisms of RP are complex, still poorly understood, and reveal multiple molecular targets, which make difficult the development of therapeutic strategies, maintaining this pathology as an orphan disease. However, although there is no cure for $\mathrm{RP}$, there has been outstanding advance in underlying genetic and molecular mechanisms to understand the pathology, which has led to restoration of vision in specific cases, such as in patients with a mutation in a gene coding for the retinal pigment epithelium protein RPE65, essential for photoreceptor physiological activity $(45,46)$. Other strategies include the implantation of prosthesis in advanced stages of RP, when most rods and cones have been inevitably lost. The progress achieved in this field is extraordinary, and clinical trials for different types of implants have proceed successfully or are expected soon $(47,48)$. Molecules studied for RP have been designed for increasing neuroprotection with the use of neurotrophic factors, decreasing cellular oxidative stress, inhibiting photoreceptor apoptosis, or attenuating retinal inflammation. Unfortunately, pharmacological approaches to RP are still experimental and their main goal is not to repair RP, but rather to slow it down, enlarging the temporal window of useful vision (49).

\section{4.- Glaucoma}

Glaucoma comprises a group of disorders characterized by a distinctive optic neuropathy that leads to progressive asymptomatic visual field loss. It is thought that loss of vision in glaucoma is associated with damage to the optic nerve and retina that results in irreversible retinal ganglion cell (RGC) damage. Glaucoma is currently the leading cause of irreversible blindness worldwide. It has been estimated that the total number of patients with glaucoma will be close to 80 million by 2020 (50). By the time patients are aware of vision loss, the disease is commonly quite advanced (51). Patients usually experience blurry or missing spots in their peripheral view (fig. 6).

Increased IOP and IOP variability are recognized as significant risk factors both for the development and progression of glaucoma. For that reason, the majority of primary openangle glaucoma treatment options focus on the management and reduction of IOP (52- 
54). Current treatments involve the use of eye drops and gels, laser treatment, or incisional surgery to achieve a lower IOP by either decreasing aqueous humor production or improving aqueous outflow (51). It is important to remark that not all glaucomatous patients experience high IOP and in many cases, the reduction of IOP does not avoid the progression of the disease.

Whatever the origin of the disease, in all glaucoma patients visual field loss is produced by RGCs death. Normal physiological ageing is responsible for an estimated rate of $0.4 \%$ RGC loss per year over approximately 1.5 million RGCs present in a healthy retina (55); in glaucoma, this percentage is increased to $4 \%$ (56). Considering the complex and multifactorial nature of glaucoma, multiple mechanisms are thought to contribute to RGC loss, such as apoptosis, necroptosis, axonal transport failure, inadequate neurotrophic factor support, excessive depolarization, mitochondrial dysfunction, excessive shortwave blue light, excessive glutamate, oxidative stress, and inappropriate RCG/glial cell interactions $(55,57-61)$. Over the past years, many publications have related glaucoma to neuroprotection.

\section{3.- MICROENCAPSULATION OF SMALL MOLECULES FOR THE TREATMENT OF CHRONIC DISEASES OF THE OPTIC NERVE AND RETINA}

The clinical application of small drug molecules has been extensively studied for the treatment of neurodegenerative pathologies affecting the posterior segment of the eye. However, their clinical application is restricted due to the fast clearance they experience that requires frequent administrations to reach therapeutic levels in the target tissues (62). This limitation can be overcome by encapsulating these drugs into delivery systems such as polymeric microspheres, which allow sustained drug release, and subsequently a reduced-dosing indication (63). Microspheres can be administered locally without surgery. Such locally injected depots provide long-term sustained drug release, thus enabling the safe dosing of drugs with pharmacokinectics issues such as a rapid systemic clearance or a narrow therapeutic window (64). Many neuroprotective agents exhibit significant side effects when administered systemically. These side effects are severe enough to limit the dose, and ultimately, the efficacy of the drug. Successful treatment strategies may involve local, sustained delivery of these drugs in a way that maximizes 
the efficacy while limiting side effect to an acceptable level. Drug loaded-microspheres are being developed with this intention as well (table 1).

\section{Corticosteroids}

Retinal vasculature diseases have become more prevalent as a result of aging population (65). Even with the growing use of anti-VEGF therapeutic agents, corticosteroids are still drugs of choice for the treatment of some of these disorders, and still are a big actor in the medical care due to their confirmed efficacy. It has been demonstrated that corticosteroids can increase tight junction integrity, protecting the blood-ocular barrier and decreasing leakage. Additionally, they have shown an antiapoptotic effect, and can protect retinal photoreceptors via activation of glucocorticoid receptors (66).

Dexamethasone (Mw $392.5 \mathrm{~g} / \mathrm{mol}$ ) is a cortical steroid that has a very short vitreous half-life (67). Since the approval from the US Food and Drug administration of Ozurdex (Allergan), a long-acting implant containing dexamethasone for the treatment of posterior segment eye diseases, the development of microparticulate sustained release systems containing steroids has gained considerable attention. Contrary to the use of the implant Ozurdex, that has to be applied with a large needle (22 gauge), microparticulate formulations can be delivered though needles from 27 to 34 gauge, avoiding invasive surgery or the use of larger devices for their application. Several studies have been made to deliver dexamethasone from microparticles prepared with biodegradable polymers. Hou H. et al. investigated pharmacokinetics and pharmacodynamics of the engineered oxidized porous silicon $\left(\mathrm{pSiO}_{2}\right)$ particles loaded with dexamethasone (width $20 \pm 5 \mu \mathrm{m}$, thickness $14.2 \pm 0.3 \mu \mathrm{m}$, porosity $50 \pm 3 \%$ ) in vitro and in vivo (68). After a 60-day in vitro release, particles demonstrated a $92 \%$ decrease by weight, indicative of $\mathrm{pSi}$ degradation and dexamethasone delivery in the dissolution chamber at $37^{\circ} \mathrm{C}$ over time. Dexamethasone concentration was at a therapeutic level at the end of the 60-day in vitro release study (12.4 ng/mL). In vivo ocular pharmacokinetics in New Zealand Red Rabbits revealed a controlled drug release sustained for at least 8 weeks without apparent ocular toxicity. The study demonstrated the utility of porous silicon dioxide microparticles as carriers for controlled release of corticoids in ophthalmology. Andrés-Guerrero V et al (69) prepared dexamethasone-loaded microspheres based on poly(ester amide)s (PEAs), which are amino acid containing biodegradable polymers combining ester an amide 
groups in the polymer chain. Their work focused on the study of the ability of PEAs to form microspheres for ophthalmic drug delivery purposes. In this study, authors showed the synthesis of the PEA polymers and the preparation, sterilization, in vitro tolerance and delivery characteristics of microspheres loaded with dexamethasone. Authors built a kinetic ocular model with in vitro release data to predict in vivo drug concentrations in a rabbit vitreous model. Then, they analyzed the behavior of PEA microspheres after injection in the subtenon space and vitreous humor of rats. Amino acid based polyesteramides were successfully formulated into microspheres $(\sim 15 \mu \mathrm{m})$, which showed good tolerance in macrophages and retinal pigment epithelial cells. Loading and release studies with dexamethasone revealed high drug encapsulation efficiency $(\sim 85 \%)$ and a controlled drug delivery for 90 days. Pharmacokinetic simulations indicated that these microspheres would provide a release of the drug in rabbit eyes up to 3 months. After $24 \mathrm{~h}$ of the administration, the injected PEA microspheres retained their morphology and coalesced into depots in the vitreous and in the subtenon space, successfully reaching the injection site, showing the utility of polyesteramide microspheres as an alternative delivery system for controlled delivery of drugs to the eye.

Triamcinolone acetonide (TA) is a synthetic corticosteroid (Mw $434.5 \mathrm{~g} / \mathrm{mol}$ ) with a 7.5-fold higher anti-inflammatory potency than cortisone. It is one of the most extensively used drugs in the treatment of several ocular diseases which are characterized by inflammation, edema and neovascularization (70). Triamcinolone acetonide is a water insoluble drug so its use in ophthalmology is available as an injectable suspension. Suspensions are required to be made with the insoluble drug in a micronized form, and are thought to be acceptable as a depot since it is assumed that the solid drug persists in the injection site giving rise to a sustained-release effect thanks to a slow dissolution rate of the poor soluble drug. However, suspensions have some disadvantages, such as not being possible to manipulate the concentration of dissolved drug due to their relative insolubility in the vehicle. For this reason and, due to the increment on the use of intraocular injections of triamcinolone in ophthalmology, the development of intraocular drug delivery systems loaded with triamcinolone has increased in the past years (5).

Cardillo el al. presented a case report with 9 patients that received intraocular injections of RETAAC, a controlled-release system based on microspheres loaded with $1 \mathrm{mg}$ triamcinolone. Authors compared the use of this system with a single intravitreal injection of $4 \mathrm{mg}$ triamcinolone for the treatment of diffuse diabetic macular edema (71). 
Quantitative measurements of central macular thickness showed a reduction from baseline exceeding 59\% (RETAAC) and 56\% (triamcinolone) at the 1- and 3-month follow-up visits respectively. The difference in central macular thickness between RETAAC and TA injected eyes was not significant because of a parallel initial pattern of regression of the macular edema. On the contrary, at $6(\mathrm{p}=0.002)$ and 12 months $(\mathrm{p}=0.002)$, RETAAC-injected eyes had thinner central macular thickness measurements compared to $4 \mathrm{mg}$ triamcinolone injected eyes. According to the authors, the findings from this preliminary report neither advocate nor support the use of triamcinolonemicrospheres for the treatment of diabetic macular edema, but imply that both RETAAC and triamcinolone injections may be well tolerated with long-term performance clearly favoring the RETAAC ( $1 \mathrm{mg}$ ) over TA ( $4 \mathrm{mg}$ ) for the anatomic and functional aspects of improvement tested in the study.

Blatsios et al. also evaluated a controlled-release system based on triamcinoloneloaded poly[DL-lactide] (PLA) microspheres (72). Authors prepared several batches with different ratios of drug/polymer (5/100 and 10/100 TA/PLA) and two preparation methods (single and double emulsion) which gave spherical microspheres $(2.09 \pm 1.11$ $\mu \mathrm{m})$ with smooth surface. Encapsulation efficiency varied depending on the method used from $50.3 \%$, to $57.9 \%$ and $77.3 \%$ for the single emulsion 10/100 and 5/100 TA/PLA, and double emulsion method 10/100 TA/PLA, respectively. The in vitro release study showed an initial burst of about $10-15 \%$ in the first day, followed by a sustained release until day 20 in all cases. Microspheres were compressed to mini-tablets (diameter $4 \mathrm{~mm}$, thickness $0.8-1 \mathrm{~mm}$ ) and episcleral implanted in rabbit eyes ex vivo. The drug diffused into the vitreous and aqueous humor rapidly during the first five days, showing a plateau in the aqueous humor at day 10 . Nonetheless, although these systems showed promising results for transcleral drug delivery, authors agreed that further studies are needed to complete the evaluation in this setting. Kadam et al. have also evaluated the use of microspheres to sustain transcleral choroidal and retinal delivery of triamcinolone acetonide (73). Triamcinolone-loaded PLA microparticles (loading 29.5\%, size $2.09 \mu \mathrm{m}$ ) were spherical and had small pores on the surface, being able to delay in 120 days the complete release of triamcinolone in vitro. In vivo delivery was assessed in control and corneal neovascularization $(\mathrm{CNV})$-induced Brown Norway rats after a single injection in the posterior subconjunctival space using a 30-gauge needle. Results showed drug levels in ocular tissues for 2 months post injection in both groups, and microparticles maintained therapeutic concentrations of triamcinolone in choroid-retinal pigment epithelial cells 
(RPE) and retina during that period of time as well. Entrapped microparticles were still observed in the periocular tissues at the end of 2 months post injection.

Zarei-Ghanavati et al. (74) evaluated the use of triamcinolone-loaded poly (lacticco-glycolic) acid (PLGA) 50:50 (Mw 40,000-75,000 g/mol) microspheres (1.9-2.5 $\mu \mathrm{m}$ size, $50-85 \%$ encapsulation efficiency) in normotensive New Zealand albino rabbits, which received an intravitreal injection of $0.1 \mathrm{~mL}$ microspheres suspension containing 4 mg of drug. At pre-set times (3, 7, 14, 28 and 56 days after the injection) triamcinolone acetonide levels in eye tissues were analyzed. After 1 week, vitreous drug concentration was $0.047-0.012$ and $0.083-0.067 \mathrm{mg} / \mathrm{mL}$ in eyes that received microspheres and triamcinolone suspension, respectively $(\mathrm{p}=0.4173)$. Although, microspheres released triamcinolone in a sustained manner, the vitreous concentration declined faster in the microparticles group in comparison to the suspension form. Authors suggested a migration of smaller microparticles throughout the vitreous cavity as a possible explanation of the results.

Budesonide (Mw $430.5 \mathrm{~g} / \mathrm{mol}$ ) is a potent non-halogenated corticosteroid that has the ability to inhibit the expression of several proinflammatory genes, inhibiting inflammatory symptoms such as edema and vascular hyperpermeability at nanomolar concentrations (75). Kompella et al. have successfully encapsulated budesonide in PLA microparticles $(3.60 \pm 0.01 \mu \mathrm{g})(76)$. Authors showed release of budesonide from PLA microparticles over a 6-week study period and a cumulative budesonide release at the end of the study of $23 \%$ of the initial drug loading. Microparticles were subconjuntivally injected in rat eyes to determine retina, vitreous, lens and cornea drug levels up to 14 days. Authors detected drug levels in all tissues of the injected eye but not in the contralateral eye, suggesting that the contribution of systemic absorption and recirculation was minimal. About drug levels on day 14, they were higher in the microparticle group compared to the solution group in all cases, showing the utility of these systems in sustaining drug delivery of budesonide in eye tissues.

\section{Nonsteroidal anti-inflammatory drugs (NSAIDs)}

Several studies have demonstrated the utility of the administration of Cyclooxigenase-2 (COX-2) selective inhibitors to reduce prostaglandin-induced retinal inflammation and blood-retinal barrier breakdown during diabetes (77-79). Celecoxib is 
a potent COX-2 inhibitor whose oral administration reduces VEGF mRNA and vascular leakage in rats (80). However, long-term oral administration of high doses of celecoxib may led to systemic toxicity (81). For that reason, the use of alternative routes such as the intravitreal and periocular, have been proposed to provide significantly higher local levels of celecoxib to the retina. In this regard, Amrite et al. (82) developed biodegradable celecoxib-loaded PLGA microparticles (mean particle size $1.11 \pm 0.08 \mu \mathrm{m}$, $\zeta$ potential $-38 \pm 0.56 \mathrm{mV}$, loading efficiency of $51.48 \% \pm 0.42 \%$ ). These particles released the drug in vitro in a biphasic manner over a period of 60 days, showing a release rate that was 38fold lower for the microparticles than with the suspension dosage form. In the diabetic animals that received celecoxib-PLGA microparticles, the PGE2 secretion was $12.2 \pm 1$ $\mathrm{pg} / \mathrm{mg}$ in the ipsilateral eye, which was significantly lower than the diabetic or diabetic + placebo groups. The levels in the ipsilateral eye in the animals that received the celecoxib microparticles were significantly lower than the levels in the contralateral eyes. The VEGF levels in the diabetic + celecoxib microparticles in the ipsilateral eye were reduced by $40 \%$ to $287 \pm 92 \mathrm{pg} / \mathrm{mg}$ protein. There was a $\sim 50 \%$ inhibition of the vascular leakage in the ipsilateral eyes of the celecoxib-PLGA microparticle-treated group. Drug levels in the ipsilateral eye were $0.66 \pm 0.33,0.79 \pm 0.34,0.23 \pm 0.1$, and $3.68 \pm 3.01 \mathrm{ng} / \mathrm{mg}$ tissue, respectively, in the sclera-choroid, retina, vitreous, and the cornea. The morphometric analysis of the retina revealed no significant differences in the thickness of the neural retina, Outer Nuclear Layer (ONL), or Inner Nuclear Layer (INL) between the celecoxibPLGA microparticle group and the control group indicating no degeneration or atrophy of the retinal tissue. Results of this study revealed the safety and effectiveness of a periocular microparticulate delivery system of celecoxib in inhibiting diabetes-induced blood-retinal barrier leakage.

Ketorolac (Mw $255.3 \mathrm{~g} / \mathrm{mol}$ ) is a drug that belongs to the group of NSAIDs which has nonselective inhibitory activity of the COX enzyme and whose neuroprotective activity has been recently studied by Nadal-Nicolás et al. (83). Authors evaluated the effect of an intravitreal solution of ketorolac or ketorolac-loaded PLGA microspheres on retinal ganglion cells survival after optic nerve crush in rats (at $0.5 \mathrm{~mm}$ from the optic disc). Microspheres (27 $\mu \mathrm{m}$ size, $114.3 \mu \mathrm{g}$ drug/mg microspheres, encapsulation efficiency $88 \%$ ) were able to release ketorolac in vitro for 30 days in a controlled fashion, showing an initial burst release effect during the first 24 hours, and delivering the drug for 30 days following a zero order release kinetic (2.34 $\mu \mathrm{g}$ ketorolac/mg MP/day). 
Ketorolac-loaded microspheres were still observed in the ventral retina 14 days after intravitreal administration. Nonetheless, regarding retinal ganglion cells survival authors observed that low ketorolac doses slowly released from microparticles were not enough to protect retinal ganglion cells in an acute injury, suggesting that this type of injury probably requires higher doses of the active substance.

\section{Photoswitch drugs}

Photoswitch compounds are light activated and enable bi-directional photocontrol of neural membrane potential. The activation of these molecules consists on a transition from their trans to cis form in light responsive manner, providing drugs that can be delivered to cells to make them light sensitive. Progress has been made on several approaches to use these compounds to restore vision to a retina devoid of rods and cones, offering a substantial hope for vision restoration in the future (84). In this regard, Groynom et al. have recently investigated the loading and delivery of quaternary ammonium-azobenzene-quaternary ammonium (QAQ) and diethylamine-azobenzenequaternary ammonium (DENAQ), molecules with high light sensitive, in microspheres prepared with PLGA and PLA, comparing their loading efficiency and release profiles, for a possible utility in ophthalmology (85). The highest amount of drug loaded into microspheres was found when systems were prepared with PLGA 502H $(51.15 \pm 17.77 \mu \mathrm{g}$ of QAQ/mg of microspheres and $62.37 \pm 18.59 \mu \mathrm{g}$ of DENAQ/mg of microspheres). This tendency was also observed in the release studies, where PLGA microspheres showed the highest cumulative release among all the systems for both QAQ and DENAQ. Approximately $87 \%$ of QAQ was released on the first 42 days, with no appreciable burst effect. For DENAQ, approximately 5\% was released on day 1 in a burst release, followed by a plateau and relatively linear release from day 7 to day 42 leading to delivery of $95 \%$ of the drug. Although the loading and delivery of the photoswitch drugs from the biodegradable microspheres showed in this study can be optimized, these might be promising results for potential therapeutic applications in the ophthalmology area. 
Table 1 Summary of small molecules microencapsulated for the treatment of chronic diseases of the optic nerve/retina

\begin{tabular}{|c|c|c|c|c|c|c|c|}
\hline \multicolumn{2}{|l|}{ Active molecules } & \multirow{2}{*}{$\begin{array}{l}\text { IDDS } \\
\mathrm{pSiO}_{2} \\
\text { microparticles } \\
\end{array}$} & \multirow{2}{*}{$\begin{array}{l}\text { Preparation method } \\
\text { Thermal oxidation }\end{array}$} & \multirow{2}{*}{$\begin{array}{l}\text { Sustained drug } \\
\text { release } \\
60 \text { days (in vitro and } \\
\text { in vivo) }\end{array}$} & \multirow{2}{*}{$\begin{array}{l}\begin{array}{l}\text { Optic nerve/Retinal } \\
\text { disease }\end{array} \\
\text { Retinal vascular } \\
\text { diseases }\end{array}$} & \multirow{2}{*}{$\begin{array}{l}\text { In vitro or in vivo } \\
\text { experiments } \\
\text { New Zealand Red } \\
\text { rabbits }\end{array}$} & \multirow{2}{*}{$\begin{array}{l}\text { References } \\
\text { Hou H et al., (68) }\end{array}$} \\
\hline \multirow[t]{6}{*}{ Corticosteroids } & \multirow[t]{2}{*}{ Dexamethasone } & & & & & & \\
\hline & & $\begin{array}{l}\text { PEAs } \\
\text { microspheres }\end{array}$ & $\begin{array}{l}\text { Solvent evaporation } \\
\text { method }\end{array}$ & 90 days (in vitro) & & $\begin{array}{l}\text { Sprague-Dawley } \\
\text { rats }\end{array}$ & $\begin{array}{l}\text { Andrés-Guerrero V et } \\
\text { al., (69) }\end{array}$ \\
\hline & \multirow[t]{3}{*}{$\begin{array}{l}\text { Triamcinolone } \\
\text { acetonide }\end{array}$} & $\begin{array}{l}\text { PLGA } \\
\text { microspheres } \\
\text { (RETAAC } \\
\text { system) } \\
\end{array}$ & $\begin{array}{l}\text { Solvent evaporation } \\
\text { method }\end{array}$ & - & & $\begin{array}{l}\text { Patients with } \\
\text { diabetic macular } \\
\text { edema }\end{array}$ & Cardillo el al. (71) \\
\hline & & $\begin{array}{l}\text { PLA } \\
\text { microspheres }\end{array}$ & $\begin{array}{l}\text { Solvent evaporation } \\
\text { method }\end{array}$ & 60 days (in vitro) & & $\begin{array}{l}\text { Cadaver New } \\
\text { Zealand rabbit } \\
\text { eyes }\end{array}$ & Blatsios et al. (72) \\
\hline & & $\begin{array}{l}\text { PLGA (50:50) } \\
\text { microspheres }\end{array}$ & $\begin{array}{l}\text { Solvent evaporation } \\
\text { method }\end{array}$ & 60 days (in vivo) & & $\begin{array}{l}\text { New Zealand } \\
\text { albino rabbits }\end{array}$ & $\begin{array}{l}\text { Zarei-Ghanavati et al. } \\
(74)\end{array}$ \\
\hline & Budesonide & $\begin{array}{l}\text { PLA } \\
\text { microparticles }\end{array}$ & $\begin{array}{l}\text { Solvent evaporation } \\
\text { method }\end{array}$ & $\begin{array}{l}15 \text { days } \\
\text { (nanoparticles) and } 42 \\
\text { days (microparticles) }\end{array}$ & & $\begin{array}{l}\text { Sprague-Dawley } \\
\text { rats }\end{array}$ & Kompella et al. (76) \\
\hline \multirow{2}{*}{$\begin{array}{l}\text { Nonsteroidal anti- } \\
\text { inflammatory drugs } \\
\text { (NSAIDs) }\end{array}$} & Celecoxib & $\begin{array}{l}\text { PLGA }(85: 15) \\
\text { microparticles }\end{array}$ & $\begin{array}{l}\text { Solvent evaporation } \\
\text { method }\end{array}$ & $\begin{array}{l}60 \text { days (in vitro and } \\
\text { in vivo) }\end{array}$ & \multirow[t]{2}{*}{ Diabetic Retinopathy } & $\begin{array}{l}\text { Sprague-Dawley } \\
\text { rats }\end{array}$ & Amrite et al. (82) \\
\hline & Ketorolac & $\begin{array}{l}\text { PLGA }(85: 15) \\
\text { microspheres }\end{array}$ & $\begin{array}{l}\text { Solvent evaporation } \\
\text { method }\end{array}$ & 42 days (in vitro) & & $\begin{array}{l}\text { Sprague-Dawley } \\
\text { rats }\end{array}$ & $\begin{array}{l}\text { Nadal-Nicolás et al. } \\
(83)\end{array}$ \\
\hline Photoswitch drugs & QAQ /DENAQ & $\begin{array}{l}\text { PLGA (50:50) } \\
\text { and PLA } \\
\text { microspheres }\end{array}$ & Emulsion technique & $\begin{array}{l}\text { 100-150 days (in } \\
\text { vitro) }\end{array}$ & Retina devoid & - & Groynom et al (85) \\
\hline
\end{tabular}




\section{4.- MICROENCAPSULATION OF PEPTIDES AND PROTEINS FOR THE TREATMENT OF CHRONIC DISEASES OF THE OPTIC NERVE AND RETINA}

The encapsulation of peptides and proteins has been one of the most fascinating defiance over the last years in the pharmaceutical technology area. In spite of their promising characteristics as therapeutic agents, they have some serious constraints. The main limit is their structural complexity and high molecular weight that have to be maintained with regard to keep their biological activity. Diverse methods like double emulsion, phase separation, hot-melt extrusion and spray drying, each one with their own conveniences and inconveniences are used to microencapsulate proteins. The method of preparation must assure the biological activity of the encapsulated biotechnological products not only during its elaboration, but also during storage and use of the microparticles (86-89). The W/O/W emulsion solvent technique is the most applied method for the preparation of these systems. Using this procedure, peptides and proteins are initially dissolved in the aqueous inner phase. However, the employment of macromolecules solution needs the evaluation of the specific assets through protein nature and further use, toward to avoid the associated potential leading dangers that might compromise its stability $(90,91)$. To bypass those risks, proteins and peptides can be microencapsulated in its solid state. It has been described that protein at solid state is kinetically cornered in the initial form, thus the conformational modification could be largely restricted $(92,93)$. In this regard, several authors are engaged on the protein microencapsulation following $\mathrm{S} / \mathrm{O} / \mathrm{O}$ methods in which the solid protein is suspended in the internal organic phase which is subsequently emulsified with an also organic external phase. Once created under these preparation conditions, protein unfolding is extremely slow (90). Although issues may rise regarding residue of oily phases that could lead to regulatory and immunity problems (94), the S/O/W method might decrease these problems. Whatever $\mathrm{S} / \mathrm{O} / \mathrm{O}$ or $\mathrm{S} / \mathrm{O} / \mathrm{W}$ approaches are used, it is essential to use a protein powder with a small particle size at the initial S/O suspension step (95). To obtain the desired protein powder this, lyophilisation of a water solution protein with additives is largely employed $(96,97)$. Moreover, the effect of lyophilisation on the biological active compound stability has been researched thoroughly, as denaturalization and aggregation are usual phenomena along freezing and subsequent dehydration, still in the presence of lyo-protectors (90). The alternative employment of spray-drying also has its constraints. 
At the moment, spray-drying is applied for protein microencapsulation. In this method, lyophilisation of protein is needed again ahead dispersion and homogenization in an organic polymer solution. Then, the protein/polymer suspension created is sprayed over a heated nozzle and organic solvent is immediately removed by a rapidly vaporization by a hot gas flow. Even though the period of airing to high temperatures is usually short, it could have an adverse impact on protein stability (90). In addition is attainable to direct spray the W/O emulsion where protein is soften in the water phase (98). The benefit of this technique is that no high temperatures are used to eliminate organic solvent. However, the creation of a W/O emulsion does not assure proteins from the unfolding and aggregation development commented beneath.

Clinical use of peptides and proteins in neurodegenerative diseases has been under investigation in the last years. Macromolecules such as anti-VEGF, neurotrophic factors, matrix metalloproteinase, erythropoietin, serpin-derived peptides, connexin mimetic peptides among others have been encapsulated in microparticles for intraocular purpose.

\section{1.- Anti-VEGF therapy}

As mentioned before, VEGF is a protein that plays a critical role in angiogenesis and vascular hyper-permeability associated with wet AMD (99). VEGF family consists of various ligands (VEGF-A, VEGF-B, VEGF-C, VEGF-D and PIGF), VEGF-A being the dominant mediator of pro-angiogenic signaling. Several therapies have been developed with the objective of inhibiting VEGF for the treatment of ocular pathologies. These therapies include VEGF inhibitors such as bevacizumab, ranibizumab and aflibercept.

Currently, the treatment of wet AMD with anti-VEGF therapies is based on onemonth injections of the active compound in solution. Unfortunately, the effect is short for a chronic disease, with estimated intravitreal half-life values of several days in all cases. That is why the benefit of these new active compounds could be largely optimized by including them in drug delivery systems able to release the compounds for longer periods of time (ideally several months). Several research groups have explored the possibility to include these new active compounds in microspheres for intravitreal administration. Some of them have focused on the development of efficient microencapsulation methods for these anti-VEGF agents and in some cases the further evaluation of the 
microencapsulated protein activity in vitro has been also performed. For example, Li et al (100) elaborated bevacizumab-loaded microspheres with PEG-PLA (PEG -5000g/mol and PLA -5000g/mol-) polymer by O/A emulsion solvent evaporation method using different emulsification techniques. The microparticles obtained $(2-10 \mu \mathrm{m})$ showed a loading efficiency of $93.6 \%$ (with an initial amount of active compound in the preparation of $5 \mathrm{mg}$ ) and were able to sustained release the protein for 91 days. Unfortunately, no bioactivity studies were performed to confirm the integrity of the protein after the microencapsulation process. Elsaid (101) prepared "Trojan" microparticles loaded with ranibizumab. They first prepared ranibizumab-loaded chitosan $(\mathrm{Mw}<400,000 \mathrm{~g} / \mathrm{mol})$ nanoparticles (elaborated by ion gelification using plain chitosan, chitosan combined with hyaluronic acid or chitosan chemically modified by the inclusion of $\mathrm{N}$-acetyl-Cys groups) The initial amount of protein included in nanoparticles was fixed in $5 \mathrm{mg}$. Subsequently the nanoparticles (17-350 nm) were included in PLGA (85:15; Mw 149,000 $\mathrm{g} / \mathrm{mol})$ microparticles by addition to the inner phase of a W/O/W emulsion. The best protein entrapment results were obtained when $\mathrm{N}$-acetyl-Cys chitosan was used, reaching a $69 \%$. Authors suggested that the presence of Cys might improve the protein solubility and also the protein entrapment by formation of disulfide bonds. When the in vitro release of the different prototypes was performed, the Trojan particles prepared with these nanoparticles showed the lowest burst effect and a prolonged release profile. Authors showed the absence of citotoxicity of the systems proposed in ARPE-19 and HUVECs cells. Furthermore, they also demonstrated that the released protein maintained its antiangiogenic nature by evaluation migration in HUVECs cells and by performing capillary-like tubules formation studies. Authors concluded that the systems created might be considered interesting platforms for the delivery of active anti-VEGF proteins after intravitreal administration.

Moreno et al (102) performed a deep analysis of different technological parameters that could influence the stability of ranibizumab and aflibercept after microencapsulation. To this, they evaluated different additives to be included in the inner phase of a W/O/W emulsion demonstrating the beneficial effect of bovine serum albumin (BSA) that partially avoided protein denaturalization during emulsification. Furthermore, they also studied the influence of different solvents and solvent combinations in O-phase of the emulsion. Among the different organic phases evaluated, triacetin and ethyl acetate 
resulted the best candidates for aflibercept microencapsulation while in the case of ranibizumab only triacetin showed significant better results in terms of protein stability.

Other authors have moved forward. Not only optimizing the microencapsulation processes of anti-VEGF compounds but also demonstrating the real utility of the systems proposed in vivo, (in healthy animals or, even better, in some cases in retinal diseases animal models).

In this sense, Yandrapu and co-workers (99), published a very interesting work exploring the combination of nano- and microparticles for the sustained release of bevacizumab. Several "Trojan prototypes" were proposed. The most successful approach involved an initial protein adsorption onto PLA (1.0 dL/g) nanoparticles $(2.5 \mathrm{mg}$ protein/500 mg PLA; final mean particle size $265 \mathrm{~nm}$ ) followed by their entrapment in PLGA $(50: 50 ; 0.67 \mathrm{dL} / \mathrm{g})$ microspheres previous porosification by the supercritical infusion and pressure quench technology. The so-prepared particles (10\% w/w PLA np content in the final formulation; microspheres final particle size $11.6 \mu \mathrm{m}$ ) led to in vitro release of the active compound in a sustained manner for 4 months. ELISA; SEC, CD and SDS-PAGE were employed to evaluate the protein stability after release demonstrating that the microencapsulation technique proposed do not alter neither the conformation nor the activity of bevacizumab. In vivo studies were performed in rats. 5 $\mu \mathrm{L}$ of microparticle suspension $(30 \% \mathrm{w} / \mathrm{v})$ were intravitreally injected in the right eye of healthy rats and the same amount of protein $(7.2 \mu \mathrm{g})$ was also administered in solution to the left eye of each animal for comparison. In eyes treated with encapsulated protein (Alexa Flour 488 conjugated bevacizumab) it was detected by noninvasive ocular fluorophotometry for two months while fluorescence disappeared two weeks after injection in eyes treated with the plain protein solution. Two months post-dosing eyes were enucleated and protein was quantified by inmmunoassay in different ocular tissues from the anterior and posterior segment. Bevacizumab was detected mainly in vitreous, retina and choroid-RPE only in eyes treated with microspheres. All these results confirmed the high potential of the new methodology proposed for microencapsulation of active proteins system for neurodegenerative diseases.

Ye and co-workers (103) used a different technological approach to create bevacizumab-loaded PLGA microspheres. In this case a $\mathrm{S} / \mathrm{O} / \mathrm{hO}$ emulsion was performed. Authors achieved pharmacokinetic studies to "provide evidences for clinical application" 
of this kind of drug delivery system. The intravitreal injection of $12.75 \mathrm{mg}$ of microspheres (protein loading of $0.098 \mathrm{mg}$ of protein/mg of microspheres and mean particle size of 2-7 $\mu \mathrm{m}$ ) was performed in the left eye of New Zealand albino-rabbits and a bevacizumab solution in the same concentration $(125 \mathrm{mg} / 0.05 \mathrm{~mL})$ was injected in the right eye. For 42 days, at several time points, three animals were sacrificed and the eyes were enucleated. The distribution of the active protein was evaluated in ocular tissues by immunofluorescence staining and its concentration in aqueous humor and vitreous was determined by ELISA. Results showed that the active protein was still present in ocular tissues 42 days post-injection, especially in retina, choroid, iris, ciliary body and anterior chamber angle. The concentration of bevacizumab in aqueous humor and vitreous after administration of microspheres was higher than of bevacizumab in solution. The pharmacokinetic parameters calculated revealed area-under-the curve values in the vitreous 2-fold higher from bevacizumab-loaded microspheres compared to the plain solution. Also important increase in $\mathrm{C}_{\max }$ values in the vitreous were observed (249 $\mu \mathrm{g} / \mathrm{mL}$ for microspheres and $156 \mu \mathrm{g} / \mathrm{mL}$ for protein solution). Results showed the utility of PLGA microcarriers for anti-VEGF proteins long-term delivery in the vitreous in the treatment of chronic retinal diseases.

In an attempt to improve the microencapsulation process Zhang et al (104) used a coaxial electrospray method to prepare PLGA microparticles loaded with ranibizumab. This method creates small drops with core-shell distribution, formed by an outer layer of organic PLGA (50:50 12,000 g/mol) solution and an inner layer of protein saline solution and ethylene glycol (final protein concentration in saline solution of $1.2 \mathrm{mg} / \mathrm{mL}$ ). The final particles, obtained after lyophilization, had a very uniform size distribution $2.4 \mu \mathrm{m}$ and high encapsulation efficiency of $70 \%$. Furthermore, the microencapsulation process occurred maintaining the protein structure according to ELISA assays. Unfortunately, authors did not perform in vitro protein release from the systems created, but, on the contrary, used a fluorescent small molecule to this (rhodamine-6G). At these conditions the microspheres were able to in vitro release the compound for one month. Also microparticles loaded with a fluorescent marker (1,1'-Dioctadecyl-3,3,3',3'tetramethylindocarbocyanine perchlorate) were employed to test the safety of the formulation in healthy animals (chick model). After intravitreal injection particles $(0.002$, $0.02 \mathrm{mg}$ and $0.2 \mathrm{mg}$ ) were distributed in various retina layers: the ganglion cells layer, the inner plexiform layer and even in the inner nuclear layer. Histological studies were 
performed one day after injection (short term study) and 12 days after injection (long term studies). No reaction (inflammation or retinal cell death) was observed, at any time of the study. However, when the number of particles was increased to $0.2 \mathrm{mg}$, microglia activation and retinal cell death was observed in the short term study. Further studies with ranibizumab-loaded microspheres would be necessary to complete this interesting technological approach.

\section{2.- Neurotrophic factors}

Neurotrophic factors are capable of attenuating or reversing neuronal degeneration. They are secreted by tissues throughout the body but are most abundant in the central nerve system. The retina contains Central Nervous System (CNS)-associated neurons making it an excellent potential site for neurotrophin therapies (105), such as BDNF (brain-derived neurotrophic factor), CNTF (ciliary neurotrophic factor) or GDNF (Glial cell-line derived neurotrophic factor), being the last one the most studied at the moment.

GDNF is a potent neurotrophic factor known to promote the development and survival of neurons. It was originally identified as a potent survival factor for midbrain dopaminergic neurons by Lin et al (106). This neurotrophin is the founding member of GDNF family ligands (GFLs), a subgroup of peptide trophic factors related to transforming growth factor- $\beta$ (TGF- $\beta$ ) superfamily. Like other neurotrophic factors, GDNF belongs structurally to the cysteine knot proteins and thus, GDNF is a disulfidelinked homodimeric protein with a molecular weight of 30,400 g/mol and a 134 amino acid sequence(107).

GDNF is widely expressed in a large variety of central and peripheral neurons with an indispensable role in growth, differentiation, and survival $(108,109)$. In this regard, the use of exogenous growth factors as GDNF have shown to be an interesting therapeutic approach for neurodegenerative diseases including Parkinson's disease, Alzheimer's disease and neurodegenerative ocular diseases (110-113). In addition, recent studies have reported that long-term expression of GDNF in photoreceptors provides a neuroprotective effects in diseases like retinitis pigmentosa (114), retinal transplants (115), glaucoma (116) and diabetic eye disease (117). In the retina, in vitro and in vivo studies have shown the potential of GDNF for rescuing retinal photoreceptors and 
ganglion cells functions during retinal degeneration (118). Moreover, GDNF seems to protect RGCs after optic nerve transection $(119,120)$ and following retinal ischemia (121). Several authors have explored the use of GDNF-loaded microspheres for the treatment of ocular diseases.

Andrieu-Soler et al. (122) prepared GDNF-loaded PLGA microspheres by W/O/W emulsion solvent evaporation method using PLGA 374.5/25. Polyethylene glycol was included in the inner aqueous phase to protect GDNF during the emulsification process. A mixture of miscible and non-miscible solvents (3:1 methylene chloride:acetone) were used in the organic phase. Particles with a mean particle size of $27 \pm 10 \mu \mathrm{m}$ were able to encapsulate $1.26 \mu \mathrm{g}$ GDNF/mg microsphere (encapsulation efficiency 92\%). In vitro release studies performed with radiolabeled GDNF, demonstrated that the created systems were able to control the release of the protein. After a burst release of the $35 \%$ of the dose in the first 24 hours, a slow delivery of the neurotrophic factor occurred at $10 \mathrm{ng} / \mathrm{day}$ for 56 days (end-point of the release study) when $60 \%$ of the total dose had been released. For in vivo experiments, $\mathrm{rd} / \mathrm{rd} 1 \mathrm{mice}$ were used. This animal model is characterized by very fast retina degeneration, with massive loss of retinal cells by day 28 post-natal. Particles were suspended in a mixture of polysorbate 80 , mannitol and carboxymethylcellulose in water $(1 \mu \mathrm{L}$ containing $0.3 \mathrm{mg}$ of microspheres, GDNF dose of $0.38 \mu \mathrm{g}$ ) and intravitreally injected. The extent of retinal degeneration was determined after animal euthanasia at post-natal day 28 , coincident with the complete photoreceptors degeneration in this animal model, 17 days after the intravitreal injection. No vitreous reaction or retinal folds were observed, demonstrating the safety of PLGA microspheres. However, in two of the 44 eyes injected with microspheres (14 with GDNF-loaded microspheres, 18 with non-loaded microspheres and 12 with GDNF-loaded microspheres in which the protein had been previously denaturalized) microspheres agglomerated close to the retina promoting retinal folds but no retinal detachment. While non treated eyes showed only one layer of cells in the ONL (56 nuclei/400 $\mu \mathrm{m}$ ), 3 to 5 rows of cells were observed in eyes treated with GDNF-loaded microspheres (123 nuclei/400 $\mu \mathrm{m})$. Interestingly, a slight high amount of nuclei was observed in animals treated with blank microspheres $(91$ nuclei/400 $\mu \mathrm{m})$ compared with the non-treated animals. An increment in rods survival was also observed for eyes treated with GDNF-loaded microspheres, in comparison to non-treated eyes and with eyes 
injected with non-loaded microspheres of with microspheres loaded with inactivated GDNF. Furthermore, after administration of GDNF-loaded microspheres it was observed a reduction of proliferation of retinal Müller in the subretinal space, in comparison to the other groups evaluated, demonstrating also a reduction in the inflammatory reaction. Finally, electroretinogram recordings were performed at shorter times (12 days after injection) to evaluate photoreceptors functionality. Rods from eyes treated with nonloaded microspheres or with microspheres loaded with denaturalized GDNF do not respond to light stimulation leading to b-wave amplitude very small. On the contrary, in the case of GDNF-loaded microspheres injected eyes there was a statistically significant increment in the b-wave amplitude, suggesting not only anatomical but functional rescue of photoreceptors. This strategy could be especially useful in diseases characterized by a loss of photoreceptors such as RP.

Ward et al (123) achieved the protection of retinal ganglion cells in a glaucoma animal model (mice) after injection of GDNF-loaded microspheres. The particles were prepared according to the W/O/W emulsion solvent evaporation method using PLGA (PLGA Resomer® 503H 50:50 Mn = 25,000). Bovine serum albumin was included in the inner aqueous phase in combination with the active protein to protect it and a mixture of methylene chloride and trifluoroethanol (1:4) was chosen as organic solvent. Microspheres (mean particle size of $10 \mu \mathrm{m}$ ) released GDNF in a sustained fashion over 71 days, preceded by an initial burst release in which the $59 \%$ of the loaded protein was delivered within the first 24 hours. The in vivo study was performed in a spontaneous glaucoma animal model (DBA/2J mice). This animal model suffers progressive retinal ganglion cells degeneration, with reduction of $30 \%$ at 8 months (called "early degeneration") and of $80 \%$ at 10 months ("late degeneration"). $1 \mu \mathrm{L}$ of microspheres suspension in PBS $(0.02 \mathrm{mg}$ of microspheres with a total GDNF dose of $0.707 \mu \mathrm{g})$ was tested in the animal model. Four protocols were performed. In three of them animals were exposed to several intravitreal injection of particle suspension each 2 months ( 3 or 4 injections). Animals were sacrificed and evaluated at 4, 6 and 8 months for protocol 1, at 13 months for protocol 2 and at 15 months for protocol 3. In a fourth protocol animals were injected only in the "late degeneration" time period (at 8 and 10 months) and were subsequently sacrificed at 12 months. Authors intended to cover both "early" and "late" RGC degeneration and "early" and "late" microspheres administration. The determination of RGC degeneration was performed by quantifying RGC densities. After 
intravitreal administration of GDNF-loaded microspheres at 2, 4 and 6 months, the "early degeneration" was evaluated, showing RGC rescue of $18.6 \%$ at 8 months. Furthermore, these animals underwent a prolonged neuroprotection without the need of further injections, so when they were evaluated at "late degeneration" stage of the disease (Protocol 3) the 15-month-old treated animals showed 3.5 times greater RGC survival in comparison with non-treated animals. Similarly, when the treatment was set at an early stage of the degeneration and it was maintained each two months until 13 months (Protocol 2) the RGC density was 2.9 higher in treated eyes. Interestingly, results from protocol 2 and 3 showed that the administration of GDNF-loaded microspheres promoted the shift in the onset of massive RGC degeneration from 8-10 months to 13-15 months. Finally, when GDNF-loaded microspheres were injected in the "late degeneration" step of the disease (at 8 and 10 months, protocol 4) also a neuroprotective effect was achieved although the RGC density in animals from this group was considerably less than densities from all others. In conclusion these authors demonstrated that GDNF released from GDNF microspheres significantly promoted RGC survival, being the early treatment alone sufficient for this survival effect. Furthermore, the RGC rescue results observed in long-term studies supported the potential of the systems created for the treatment of chronic neurodegenerative diseases such as glaucoma. One year later, Jiang et al (124) evaluated GDNF-loaded microspheres (elaborated with the same protocol) in a rat model of glaucoma. This animal model is created by injection of hypertonic (1.9 M) saline solution into the episcleral vein, which promotes a chronically elevated IOP for eight weeks that simulates glaucoma events in the retina and optic nerve. GDNF loaded microspheres were suspended (at 2 and 10\%) in PBS and intravitreally injected. Animals treated with the higher microspheres concentration showed significant increase in RGC and axon survival, a reduction in the loss of retinal IPL (inner plexiform layer) thickness and a decrease glial activation in both retina and optic nerve, compared with non-loaded microspheres. Furthermore, the treatment with loaded GDNF microspheres moderately reduced cupping on the optic nerve head. Later, Kyhn et al (121) evaluated the neuroprotective effect of the same GDNF-loaded PLGA microspheres (prepared according to Ward et al., 2007) in a pig model of acute retinal ischemia. In this work microspheres ( $2 \mathrm{mg}$ in $0.2 \mathrm{~mL}$ of PBS; total GDNF dose of $70.7 \mu \mathrm{g}$ ) were intravitreally injected three days after the ischemia insult. The left eye was injected with loaded and non-loaded microspheres and the right eye of each animal was left as control. Histological studies were performed after animals' sacrifice at the end of the study (day 42-49 post 
injection) to evaluate potential retinal damage and to quantify cells in the RGC layer. In the animal model used, the pressure-induced retinal ischemia affects the inner retinal layer, the RGC layer becomes pathologically thin or almost absent with the nerve fiber layer thinned as well. Furthermore, edema appears in the plexiform layers and the inner nuclear layer. However, for animals treated with GDNF-loaded microspheres less destruction of the inner retinal layers, including the RGC layer was observed, in comparison to non-treated retina and with retinas treated with non-loaded microspheres. Quantitatively, the neuroprotective effect of the microsystems proposed was demonstrated by immunohistochemical detection of nuclei in the RGC layer. Eyes injected with GDNF-loaded microspheres showed RGC presence more than double that seen with blank microspheres. This increase in RGC cells was corroborated by an improvement in the retinal functionality, according to the multifocal electroretinography studies performed.

Checa-Casalengua et al (116) also evaluated the neuroprotective effect of GDNFloaded microspheres Using PLGA 50:50 (Resomer® 503 35,000 g/mol). In this case rats with chronic elevation of IOP, generated via episcleral vein injection of hypertonic saline were used as animal models. A new microencapsulation method for proteins was proposed by the research group based on the $\mathrm{S} / \mathrm{O} / \mathrm{W}$ emulsion method. The novelty of the technique was based on two facts. On one hand, the protein was not pre-treated before encapsulation and always remained in its solid state. On the other hand, an oily additive (Vit E) was included in the internal phase, promoting additional protein protection, release modulation and pharmacological activity itself (antioxidant) (125). The microspheres prepared (mean particle size $19 \mu \mathrm{m} ; 25.4 \mathrm{ng}$ GDNF/mg microspheres (MS)) released in a controlled manner the protein for 133 days. Initially, a burst effect was observed with $16 \mathrm{ng}$ GDNF/mg MS delivered in the first 24 hours. After that, several steps of relatively rapid and slow release appeared: at $117.3 \mathrm{pg}$ GDNF/mg MS for the following 41 days, at $175.2 \mathrm{pg}$ GDNF/mg MS from day 42 to day 77 and at $13.5 \mathrm{pg}$ GDNF/mg MS form day 77 to the end of the assay. The biological integrity of the protein after the microencapsulation and release process was demonstrated by bioactivity assays using photoreceptor explants and cultured RGCs. For the in vivo studies $5 \mu \mathrm{L}$ of a microspheres suspension in PBS (0.5\% of microspheres, GDNF total dose of $0.64 \mathrm{ng}$ ) was intravitreally injected in animals one week after increase of IOP. Eleven weeks postinjection animals were sacrificed and RGC cells were quantified by counting anti-NeuN 
positive cells in the ganglion cells layer. In healthy rats values close to 67 cells $/ \mathrm{mm}$ were observed, while in non-treated glaucomatous animals of animals receiving non-loaded microspheres this values drops to approximately 20 cells $/ \mathrm{mm}$. In eyes treated with GDNF/Vit E loaded microspheres values around 51 cells/mm were obtained, demonstrating the ability of the microsystem to rescue RGC. Furthermore, the treatment proposed was also found to have positive effect on optic nerve axonal preservation, with survival values of $73 \%$, in contrast to values around $30 \%$ of survival obtained from nonloaded microspheres of with the same dose of GDNF administered as bolus in solution. No obvious side effects on the retinal integrity were noted.

\section{3.- Other therapeutic proteins and peptides}

While most of the works developed until now are focused on the intraocular administration of anti-VEGF compounds and neurotrophic factors, other proteins and peptides have already emerged as interesting active macromolecules to be microencapsulated for the treatment of ocular diseases.

Yao et al (126) microencapsulated matrix metalloproteinase 2 (MMP-2) and coadministered the particles in the subretinal space with retinal progenitor cells. MMP-2 is a protein (Mw approx 72,000 $\mathrm{g} / \mathrm{mol}$ ) able to degrade cell adhesion molecules such as CD44 and neurocan involved in the maintenance of the inhibitory extracellular matrix subretinal barrier. The interesting strategy explored in this paper was to use a slow release of MMP-2 as coadjuvant to enhance the celular integration and promote retinal repopulation. Particles were prepared using PLGA (Resomer® 502, 14,000 g/mol) by $\mathrm{W} / \mathrm{O} / \mathrm{W}$ emulsion solvent evaporation method. The microencapsulation conditions were optimized to create microspheres able to release the protein in one week, time necessary to degrade inhibitory extracellular matrix and to allow transplanted cells migration without disruption of host retina. Rho-/- mice were used as retinal degenerative recipient animals in this study. $1 \mu \mathrm{L}$ of microspheres (10-20 $\mu \mathrm{m}$ range of particle size) suspension ( $5 \mathrm{ng} / \mathrm{mL}$ of released active MMP2) was mixed with RPCs $\left(2 \times 10^{5} / \mu \mathrm{L}\right)$ and subretinaly injected. CD44 and neurocan quantification was performed by immunohistochemistry during the following 5 days in eyes from different animal groups. Coincident with the in vitro peak MMP-2 release at day 3, an important reduction of both molecules was observed also in vivo at the same time. This fact was related with a significantly higher retinal progenitor cells migration into the retina, aproximately 3 -folds at day 3 and 2 -folds 
at day 5 after injection in comparison to control groups, demonstrating that the strategy proposed can be an interesting tool for retinal repair.

Erythropoietin (EPO) is another promising candidate in the treatment of ocular diseases. It is 165 amino acid peptide with a 30,000 g/mol protein. It owns four glycosylation sites and thus controls the half-life in bloodstream. It's mainly produced in kidney and fetal liver (127). EPO has been demonstrated to be useful in RGC, photoreceptors and RPE cells protection against acute damage and also to offer antiapoptotic activity. Furthermore, it stimulates neurite regrowth in RGCs after axotomization $(128,129)$ This neuroprotective and neurodegenerative behavior makes EPO an excellent candidate for microencapsulation and intraocular delivery in the treatment of retinal and optic nerve diseases. Rong et al (130) prepared EPO-dextranPLGA/PLA microspheres (PLGA(50:50):PLA ratio 4:6) for intravitreal administration. During the microencapsulation process they first prepared EPO-dextran particles by dissolution of both compounds in PEG and water. The solution was lyophilized and the powder obtained was suspended in methylene chloride to eliminate PEG. This washing process was repeated five times to obtained the EPO-dextran particles that were then microencapsulated in PLA/PLGA matrices by the S/O/W emulsion method. The EPO in vitro release from the resulting microspheres (PLA/PLGA microspheres in the 40-100 $\mu \mathrm{m}$ range) was characterized by an initial burst in which $20 \%$ of the initial dose was released followed by a sustained release in almost 80 days (final \% dose released 90\%). Unfortunately authors did not measured the dextran-EPO particle size. However, regarding the low burst effect found, authors claimed that it should be less than 1/20 of diameter of the PLA/PLGA microspheres. The incubation of retina explants with release media and posterior observation under a phase-contrast light microscopy showed no significant differences with EPO fresh solution in terms of neurites' density and length, demonstrating that the microencapsulation procedure employed in this work preserved the protein bioactivity. In vivo studies were performed in rats with damaged retinas due to an optic nerve crush. In this model RGC apoptosis massively occurred, reaching a peak of $30 \%$ apoptotic rate one week after the insult and being still observable for up six weeks. The intravitreal injection of $1 \mathrm{mg}$ of microspheres in PBS (total EPO dose of $0.125 \mu \mathrm{g}$ ) was performed immediately after the retinas' insult. Also another animal group was treated with EPO solution in PBS every two weeks (EPO dose of $0.0312 \mu \mathrm{g} / \mathrm{injection}$ ). Non-loaded microspheres suspension in PBS and PBS injections were also performed in 
control groups. Several analyses were performed to determine the retina status after optic nerve crushing for eyes treated and untreated. For the first two weeks after damage retinas were compared in terms of apoptotic activity via TUNEL study, showing significantly fewer apoptotic RGCs for both groups treated with EPO microspheres and with EPO solution, $11 \%$ and $12 \%$ of RGC apoptosis respectively one week after the insult. Furthermore, two weeks after the damage, a reduction of proliferation of retinal Müller in the subretinal space for groups treated with EPO (both microencapsulated and administered in solution) was observed after determination of glial cells activation in retina. On the contrary, non-treated animals showed an increment in this parameter, related with inflammatory events, with a peak at two weeks after optic nerve crushing. Also, to determine the prolonged neuroprotective effect of the microspheres proposed on RGC survival, a retrograde labeling of RGCs was performed 4 and 8 weeks after insult. The mean density of survival RGCs in EPO microspheres and EPO solution treated groups increased in comparison to control and non-treated groups. Globally, this work demonstrated that EPO dextran-PLA/PLGA microspheres showed a prolonged neuroprotective effect by promoting RGC survival and partially delaying RGC apoptosis in the same extent that multiple EPO solution injections, regardless of the side effects caused by repeated injections. Two years later, the same authors published another work focused on the evaluation of the tolerance of the EPO-dex PLA/PLGA microspheres after intravitreal administration in rabbits (5 $\mathrm{mg}$ of microspheres/0.1 mL of PBS) (131). Tolerance evaluation was performed 1, 2, 4, 8, and 12 weeks after injection. Microspheres remained in the lower part of the vitreous of the injected eyes and gradually degraded and disappeared at 11 weeks post-injection. No any RGC apoptosis or glial cell activation were observed in treated eyes. Furthermore, the retinal inner structure remained unaltered by the presence of microspheres. Neither retinal detachment nor inflammatory reactions occurred after injection. Not only structural, but also retina functionality evaluation was performed by electroretinogram, showing no changes in the b-wave amplitudes after blank PLGA microspheres injection.

Some authors have explored the possibility of using serpin-derived peptides in the treatment of choroidal neovascularization (132). These compounds are able to inhibit angiogenesis by both inducing endothelial cell apoptosis as well as decreasing their migration by increasing adhesion. One of these peptides, named "SP6001" was microencapsulated and evaluated in a laser-induced choroidal neovascularization mouse 
model (NVAMD) in vivo. Before the microencapsulation process, it was complexed with a biodegradable cationic polymer (poly-beta amino ester, PBAE) thanks to the negative charge of the peptide due to the presence of glutamate residues, in order to protect the peptide form degradation and to extend the delivery. The nanoparticles created (mean particle size of $119 \mathrm{~nm}$ ) were tested alone or microencapsulated in PLGA microspheres prepared by the inclusion of the peptide nanoparticles in the inner aqueous phase following a W/O/W emulsion solvent evaporation method (PLGA 65:35 Mw 40,00075,000). The so prepared microspheres (mean particle size $12 \mu \mathrm{m}$; peptide encapsulation efficiency around $70 \%$, with an initial amount of $0.25 \mathrm{mg}$ of peptide in the formulation) showed a cero-order kinetic release for 140 days (without burst effect) at a rate of $8 \mathrm{ng}$ of peptide/mg of particle/day, followed by a slightly slow release phase for additional 60 days. The animal model used in this work undergoes Brunch's membrane rupture, which induces neovascularization in the damaged zone. Two weeks after the insult animals were perfused with a fluorescein-dextran solution to easily detect any leakage in retina due to neovascularization. Immediately after insult, the intravitreal injection of loaded microspheres, loaded nanoparticles or peptide solution were performed in different animal groups maintaining a peptide total dose in all cases of $0.1 \mu \mathrm{g}$. At short periods (24 weeks) both loaded nano- and microparticles showed significant suppression of choroidal neovascularization according to the measurement of neovascularizated areas. Interestingly, for longer periods of time, the suppression of the neovascularization was only observed in eyes treated with the microencapsulated peptide. This effect was observed up 14 weeks after single injection. Fundus photographs showed slow disappearance of the microspheres from vitreous that correlated well with the antiangiogenic effect observed. This in vivo microspheres' degradation was at least twice as fast as observed in vitro. Authors explained this phenomenon due to the microenvironment in the eye that contains enzymes and clearance mechanism not considered in the in vitro release study.

Chen et al. (133) explored a very interesting alternative to promote RGCs survival after retinal injure. They nano- and microencapsulated connexin43 mimetic peptide, a macromolecule able to provide RGC protection against the increment in blood-brain barrier permeability and the endothelial cell loss that occurs after retinal ischaemia when Cx43 hemichannels are open in a uncontrolled manner. Nanoparticles (mean particle size $113 \mathrm{~nm}$; entrapment efficiency 70\%) and microparticles (mean particle size $9 \mu \mathrm{m}$; 
entrapment efficiency 97\%) were prepared using the W/O/W emulsion solvent evaporation method (PLGA 50:50; Mw 13,600 g/mol). After initial burst effect (46\% for nanoparticles and $29 \%$ for microparticles), sustained release of the peptide was observed for both preparations. While nanoparticles were able to release the active compound for 63 days, microparticles extended this delivery time to 112 days. The bioactivity of the encapsulated peptide was in vitro confirmed by evaluating the block of $\mathrm{Cx} 43$ hemichannel in ARPR-19 cells after 8 hours incubation with loaded nano- and microparticles. According to this study, particles were able to protect the peptide from degradation, sustain its release and therefore prolong its activity. The systems proposed were evaluated in a retinal ischaemia-reperfusion rat model. In this model the Cx43 hemichannel becomes significantly upregulated and an increment in astrocytes activation is promoted in the ischaemic region. These events provoke a significant loss of RGCs at 28 days showing large patches devoid of RGC in many areas with only $70 \%$ of RGC survival. Furthermore, there is an almost complete loss of blood vessel delineation. The administration of peptide-loaded nanoparticles and microparticles was performed immediately after insult ( $2 \mu \mathrm{L}$ of $580 \mu \mathrm{M}$ peptide in $0.9 \%$ saline solution) and the potential beneficial effect was observed 28 and 90 day after. Eyes treated with the peptide in solution or nanoencapsulated offered fewer patches of RGC loss at 28 and 90 days. Although loaded microparticles also reduced Cx43 levels at 28 and 90 days, this was not reflected in any RGC rescue. This behavior was explained to insufficient initial peptide release from microparticles immediately after retinal damage. Furthermore, according to authors, the larger size of microparticles might hinder their diffusion through the vitreous to the retina increasing the risk of enzymatic degradation. However, it was concluded that microparticles treatment may still provide long-term RGC protection and thus has significant potential in the treatment of chronic retinal and choroidal inflammatory conditions.

Isiegas et al (134) evaluated the useful of microencapsulation of proinsulin as new therapy in the protection of photoreceptors and intravitreally tested the system proposed in a mouse model of retinitis pigmentosa. Proinsulin ( $\mathrm{Mw}$ approx $10,000 \mathrm{~g} / \mathrm{mol}$ ) is not only a low-activity precursor of pancreatic insulin, but it is also produced in other tissues and has shown the ability to delay photoreceptors death in retinitis pigmentosa animal models $(135,136)$. Microspheres were prepared by W/O/W emulsion solvent evaporation method using PLGA (50:50 Resomer $®$ RG503H) as polymer matrix. Particle size ranged 
from 10 to $32 \mu \mathrm{m}$ with an active compound loading of $3.2 \mu \mathrm{g} / \mathrm{mg}$ microspheres. The in vitro release profile of the formulation selected showed an important initial burst when more than $60 \%$ of the total amount of encapsulated protein was released, followed by a sustained delivery of proinsulin for 45 days with a final accumulated release of $90 \%$ of the total loaded molecule. According to authors, this initial important release might contribute to the neuroprotective effect expected for the systems created. The animal model selected for this study, $r d 10$ mice, is characterized by a spontaneous mutation of the rod-phosphodiesterase (PDE) gene, leading to a rod degeneration that starts around P18 and is also followed by cones loss. The photoreceptor death reaches a peak around P25 (137). Animals were intravitreally treated with loaded microspheres (total protein dose $22.42 \mathrm{ng}$ ) at P14 or P15, before the onset of any photoreceptor degeneration. As control, the contralateral eye was injected with non-loaded microspheres. Retinas were evaluated at P25 in terms of photoreceptor preservation by determination of outer nuclear layer thickness and the number of cell rows. Eyes treated with proinsulin-loaded microspheres showed higher ONL thickness and number of rows all over the different retina sections evaluated from nasal to temporal zones. The attenuation of cell death for treated eyes was also observed in retinal organotypic studies ad P22. Furthermore, authors evaluated retina functionality by electroretinography. In this animal model the electroretinography $(\mathrm{ERG})$ reveals alterations in the physiology of the inner retina as early as P18 (before any obvious morphological change of inner neurons) and yet consistently with a reduced band amplification by bipolar cells (137). Results demonstrated that the treatment with loaded microspheres significantly increased the b-cone, b-mixed and oscillatory potential amplitudes compared with values obtained for eyes injected with non-loaded microspheres. According to authors, these results might be explained by a reduction in rod cell death, leading to structural improvement in the retina and also a neuroprotective effect on synapses between rods and bipolar cells improving their functionality. 
Table 2: Summary of peptides and proteins microencapsulated for the treatment of chronic diseases of the optic nerve/retina

\begin{tabular}{|c|c|c|c|c|c|c|c|}
\hline \multicolumn{2}{|c|}{ Active molecules } & \multirow{2}{*}{$\begin{array}{l}\text { IDDS } \\
\text { PEG-PLA microspheres }\end{array}$} & \multirow{2}{*}{$\begin{array}{l}\begin{array}{l}\text { Preparation } \\
\text { method }\end{array} \\
\text { O/A emulsion } \\
\text { solvent } \\
\text { evaporation } \\
\text { methods } \\
\end{array}$} & \multirow{2}{*}{$\begin{array}{l}\text { Sustained drug release } \\
91 \text { days }\end{array}$} & \multirow{2}{*}{$\begin{array}{l}\begin{array}{l}\text { Optic } \\
\text { nerve/Retinal } \\
\text { disease }\end{array} \\
\text { Age-related } \\
\text { macular } \\
\text { degeneration }\end{array}$} & \multirow{2}{*}{$\begin{array}{l}\text { In vitro or in vivo } \\
\text { experiments }\end{array}$} & \multirow{2}{*}{$\begin{array}{l}\text { References } \\
\text { Li et al (91) }\end{array}$} \\
\hline $\begin{array}{l}\text { Anti-VEGF } \\
\text { agents }\end{array}$ & Bevacizumab & & & & & & \\
\hline & Ranibizumab & 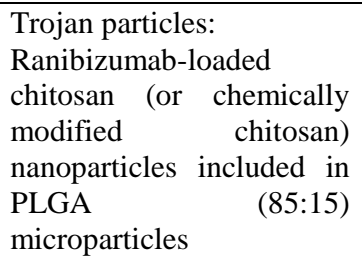 & $\begin{array}{l}\text { Nanoparticles: ion } \\
\text { gelation method. } \\
\text { Microparticles } \\
\text { W/O/W emulsion } \\
\text { solvent } \\
\text { evaporation } \\
\text { methods }\end{array}$ & $\begin{array}{l}\text { The best prototypes offer } \\
\text { release periods higher } \\
\text { than } 180 \text { days }\end{array}$ & & $\begin{array}{l}\text { Bioactivity and cytotoxicity in } \\
\text { vitro studies (ARPE-19 and } \\
\text { HUVECs cell lines) }\end{array}$ & $\begin{array}{l}\text { Elsaid } \\
(101)\end{array}$ \\
\hline & $\begin{array}{l}\text { Ranibizumab / } \\
\text { Aflibercept }\end{array}$ & $\begin{array}{l}\text { No polymer employed } \\
\text { (article focused on protein } \\
\text { stability) } \\
\text { BSA included in the inner } \\
\text { phase to protect } \\
\text { Ranibizumab /aflibercept }\end{array}$ & $\begin{array}{l}\text { W/O/W emulsion } \\
\text { solvent } \\
\text { evaporation } \\
\text { methods }\end{array}$ & Non performed & & In vitro technological studies & $\begin{array}{l}\text { Moreno et } \\
\text { al (93) }\end{array}$ \\
\hline & Bevacizumab & $\begin{array}{l}\text { Trojan particles: } \\
\text { Bevacizumab adsorption } \\
\text { onto PLA nanoparticles } \\
\text { included in PLGA (50:50) } \\
\text { microspheres }\end{array}$ & $\begin{array}{l}\text { Supercritical } \\
\text { infusion and } \\
\text { pressure quench } \\
\text { technology }\end{array}$ & 4 months & & $\begin{array}{l}\text { In vivo pharmacokinetic } \\
\text { studies (healthy rats) }\end{array}$ & $\begin{array}{l}\text { Yandrapu } \\
\text { et al (90) }\end{array}$ \\
\hline & Bevacizumab & $\begin{array}{l}\text { PLGA } \\
\text { microspheres }\end{array}$ & $\begin{array}{l}\mathrm{S} / \mathrm{O} / \mathrm{O} \text { emulsion } \\
\text { solvent } \\
\text { evaporation } \\
\text { methods }\end{array}$ & Non performed & & $\begin{array}{l}\text { In vivo pharmacokinetic } \\
\text { studies (healthy rabbits) }\end{array}$ & $\begin{array}{l}\text { Ye et al } \\
(103)\end{array}$ \\
\hline
\end{tabular}




\begin{tabular}{|c|c|c|c|c|c|c|c|}
\hline & Ranibizumab & $\begin{array}{l}\text { PLGA microparticles: } \\
\text { Inner layer - protein and } \\
\text { ethylene glycol } \\
\text { Outer layer -PLGA (50:50) }\end{array}$ & $\begin{array}{l}\text { Coaxial } \\
\text { electrospray } \\
\text { method }\end{array}$ & $\begin{array}{l}\text { Non performed } \\
\text { (rhodamine-6G loaded } \\
\text { microparticles were able } \\
\text { to release the marker for } 1 \\
\text { month) }\end{array}$ & & $\begin{array}{l}\text { In vivo tolerance studies with } \\
\text { microspheres loaded with } \\
\text { fluorescent marker (healthy } \\
\text { chicken). } \\
\text { No in vivo studies were } \\
\text { performed with ranibizumab } \\
\text { loaded microparticles }\end{array}$ & $\begin{array}{l}\text { Zhang et al } \\
(104)\end{array}$ \\
\hline \multirow[t]{4}{*}{ Neurotrophins } & \multirow[t]{4}{*}{$\begin{array}{l}\text { Glial cell-line } \\
\text { derived } \\
\text { neurotrophic } \\
\text { factor (GDNF) }\end{array}$} & $\begin{array}{l}\text { PLGA }(37.5 / 25) \\
\text { microspheres: } \\
\text { PEG (400) included in the } \\
\text { inner phase to protect } \\
\text { GDNF }\end{array}$ & $\begin{array}{l}\text { W/O/W emulsion } \\
\text { solvent } \\
\text { evaporation } \\
\text { methods }\end{array}$ & 56 days & $\begin{array}{l}\text { Retinitis } \\
\text { pigmentosa }\end{array}$ & $\begin{array}{l}\text { In vivo efficacy studies in } \mathrm{rd} / \mathrm{rd} \\
1 \text { mice }\end{array}$ & $\begin{array}{l}\text { Andrieu- } \\
\text { Soler et al. } \\
(122)\end{array}$ \\
\hline & & $\begin{array}{l}\text { PLGA } \\
\text { (50:50)microspheres: } \\
\text { BSA included in the inner } \\
\text { phase to protect GDNF }\end{array}$ & $\begin{array}{l}\text { W/O/W emulsion } \\
\text { solvent } \\
\text { evaporation } \\
\text { methods }\end{array}$ & 71 days & Glaucoma & $\begin{array}{l}\text { In vivo efficacy studies in a } \\
\text { spontaneous glaucoma animal } \\
\text { model (DBA/2J mice) }\end{array}$ & $\begin{array}{l}\text { Ward et al } \\
(123)\end{array}$ \\
\hline & & $\begin{array}{l}\text { PLGA } \\
\text { microspheres }\end{array}$ & $\begin{array}{l}\text { W/O/W emulsion } \\
\text { solvent } \\
\text { evaporation } \\
\text { methods }\end{array}$ & & Retinal ischemia & $\begin{array}{l}\text { In vivo efficacy studies in a pig } \\
\text { model of acute retinal } \\
\text { ischemia }\end{array}$ & $\begin{array}{l}\text { Kyhn et al } \\
(121)\end{array}$ \\
\hline & & $\begin{array}{l}\text { PLGA (50:50) } \\
\text { microspheres: } \\
\text { GDNF in solid state } \\
\text { GDNF/oil additive (Vit E) } \\
\text { suspension included in the } \\
\text { internal phase }\end{array}$ & $\begin{array}{l}\mathrm{S} / \mathrm{O} / \mathrm{W} \text { emulsion } \\
\text { solvent } \\
\text { evaporation } \\
\text { methods }\end{array}$ & 133 days & Glaucoma & $\begin{array}{l}\text { In vitro bioactivity assays } \\
\text { (photoreceptor explants and } \\
\text { cultured RGCs) } \\
\text { In vivo efficacy assays in } \\
\text { glaucoma animal model (rats) } \\
\text { of chronic IOP elevation }\end{array}$ & $\begin{array}{l}\text { Checa- } \\
\text { Casalengua } \\
\text { et al (116) }\end{array}$ \\
\hline \multirow[t]{2}{*}{$\begin{array}{l}\text { Other } \\
\text { therapeutic } \\
\text { proteins and } \\
\text { peptides }\end{array}$} & $\begin{array}{l}\text { Matrix } \\
\text { metalloproteinase } \\
2 \text { (MMP-2) }\end{array}$ & $\begin{array}{ll}\text { PLGA } & (50: 50) \\
\text { microparticles }\end{array}$ & $\begin{array}{l}\text { W/O/W emulsion } \\
\text { solvent } \\
\text { evaporation } \\
\text { methods }\end{array}$ & One week & $\begin{array}{l}\text { Retinal } \\
\text { degeneration } \\
\text { (Celular } \\
\text { integration and } \\
\text { promote retinal } \\
\text { repopulation) } \\
\end{array}$ & $\begin{array}{l}\text { In vivo efficacy studies in } \\
\text { Rho-/- mice }\end{array}$ & $\begin{array}{l}\text { Yao et al } \\
(126)\end{array}$ \\
\hline & Erythropoietin & $\begin{array}{l}\text { EPO-dextran nanoparticles } \\
\text { in PLGA/PLA } \\
\text { (PLGA(50:50):PLA ratio } \\
\text { 4:6) microspheres }\end{array}$ & $\begin{array}{l}\mathrm{S} / \mathrm{O} / \mathrm{W} \text { emulsion } \\
\text { solvent } \\
\text { evaporation } \\
\text { methods }\end{array}$ & 80 days & Non specified & $\begin{array}{l}\text { In vitro bioactivity assays } \\
\text { (retinal explants) } \\
\text { In vivo efficacy assays in } \\
\text { retinal damage animal model } \\
\text { (rats) due to optic nerve crush }\end{array}$ & $\begin{array}{l}\text { Rong et al } \\
(130)\end{array}$ \\
\hline
\end{tabular}




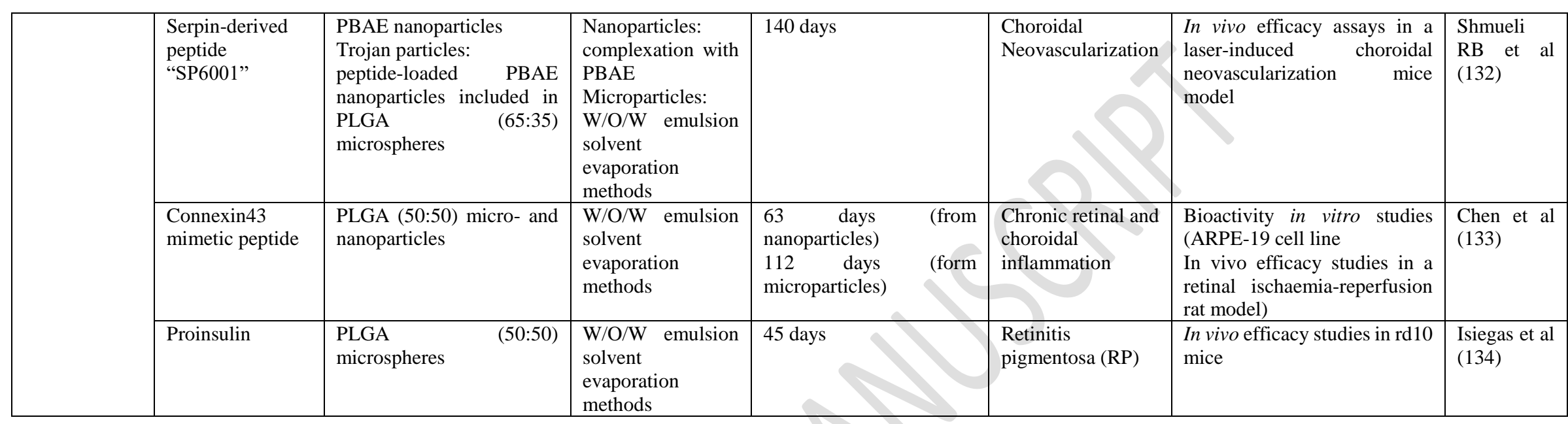


4.4.- Other uses of protein microencapsulation involved in the study of optic nerve and retinal diseases. Animal models.

Due to the difficulty of simulate adverse conditions in chronic diseases, different strategies have been assayed. Two pioneer research works from 1998 and 2001 already explored the utility of protein-loaded microparticles, not to treat ocular diseases but, on the contrary, to progressively induce damage in animal retinas simulating events typically occurring in ocular diseases, such as neovascularisation. Kimura et al (138) prepared cross-linked gelatine microspheres loaded with b-FGF (basic fibroblast growth factor) by polyion complexation. b-FGF is a prominent promoter of endothelial cell migration and proliferation that stimulates the angiogenic effect. After subretinal injection, particles (mean particle size of 40 microns) induced a foreign body reaction from the first week after injection. Two weeks post-implantation several events promoted the formation of new subretinal vascular vessels, not only due to the inherent effect of the loaded protein but also to the release of soluble compounds of infiltrating macrophages and RPE such as VEGF. Interestingly authors observed that the choroidal neovascular membranes created resulted immunohistochemicaly similar to those developed in AMD. Cleland et al (139) prepared microparticles intended for the development of ocular diseases animal models as well. They performed poly-glycolic acid microspheres loaded with VEGF. In a first step VEGF particles were prepared by spray-freezing procedure including different agents to improve the protein stability (trehalose or polysorbate). Subsequently, the so

prepared protein was included in PLGA microspheres also prepared by spray-freezing and further organic solvent extraction (PLGA 50:50 RG502 and RG502H). Authors tested these microparticles with therapeutic purposes for the induction of neovascularisation in isquemia regions; however authors also explored the potential of VEGF-loaded microspheres to increase angiogenensis after intravitreal and subretinal injection. In both cases an increase in retinal vessels dilation and the appearance of tortuous new vessels was observed five days post implantation.

\section{5.- CONCLUSIONS AND FUTURE TRENDS}

Neurodegenerative diseases of the posterior segment of the eye are directly related with blindness. These pathologies have in common that the target site is the retina (or close to retinal areas), systemic and topical treatments are not effective (due to the presence of ocular effective barriers) and most of them are chronic, multifactorial and elderly related. 
Patients suffering these diseases can gain benefits from the use of drug delivery systems, to slow down the progression of the neurodegenerative events.

One of the most challenging areas in ophthalmology therapy is to decrease the number of invasive interventions. This objective can be achieved by the combination of active substances and/or the development of drug delivery systems. Currently, retina specialists are taking into consideration the utility of the combination of active substances that target different pathophysiological mechanisms in retinal complex pathologies. The combination of active substances in these therapies has been demonstrated to have benefits in comparison with monotherapy. For example in diabetic macular edema (DME), a pathology involving vascular endothelial growth factor (VEGF) and other inflammatory mediators (140). Although DME is currently first-line treated with intravitreal anti-VEGF therapies, some patients are refractory to multiple anti-VEGF treatments. In these cases a combination therapy of Anti-VEGF with corticosteroids appears a promising alternative (7). Similar therapeutic strategies have been also employed in the management of neovascular age-related macular degeneration. Thanks to this combination authors have described an overall reduction in the required ranibizumab re-treatments compared with ranibizumab monotherapy $(141,142)$. The use of combined therapy in AMD has been extended to non-steroidal antiinflammatory drugs. In fact, bromfenac combined with the anti-VEGF in the treatment of wet AMD has resulted more effective than single aflibercept therapy (143).

Long term delivery of different active substances can be achieved with the use of multiloaded drug delivery systems avoiding successive injections. Microspheres can contain different drugs being released in a controlled fashion. Thanks to this therapeutic strategy, an improvement in the chronic treatment of neovascular AMD and DR could be gained. Combined neuroprotection from biodegradable microspheres can be extended to glaucoma by lowering the degeneration occurring in subjects with high levels of IOP as well as in normotensive patients. The controlled release of several combinations such as biotechnological products with low molecular weight active substances or even several low molecular weight drugs with different mechanism of action will result of great interest in the coming future.

The use of microspheres could result beneficial as a combined therapy to be used in inherited neurodegenerative diseases. In this case, the combination of gene therapy with 
neuroprotective drug delivery would be of great interest. The advances in gene therapy and the on-going clinical trials support the fact that this kind of treatments could become available in the next coming future. With the help of the slow delivery of neuroprotective substances a more rational therapy is available.

The combination of several technological strategies in the same formulation can be an interesting tool to improve the benefit of active compounds as well. For example, Osswald and Kang-Mieler recently prepared PLGA microspheres loaded with anti-VEGF agents (ranibizumab or aflibercept) and included them in an injectable thermosresponsive hydrogel. This combination allowed the extension of the bioactive compounds in vitro release over almost 200 days at constant rate after initial burst release (144).

Microspheres are also emerging tools in the development of chronic animal models of degeneration that allow a more physiological approach to the events occurring in the clinical scenario. 


\section{7.- REFERENCES}

1. Tian K, Shibata-Germanos S, Pahlitzsch M, Cordeiro MF. Current perspective of neuroprotection and glaucoma. Clin Ophthalmol. 2015;9:2109-18.

2. McGuinness MB, Karahalios A, Finger RP, Guymer RH, Simpson JA. AgeRelated Macular Degeneration and Mortality: A Systematic Review and Meta-Analysis. Ophthalmic Epidemiol. 2017:1-12.

3. Liew G, Wong VW, Ho IV. Mini Review: Changes in the Incidence of and Progression to Proliferative and Sight-Threatening Diabetic Retinopathy Over the Last 30 Years. Ophthalmic Epidemiol. 2017:1-8.

4. $\quad \mathrm{Xu} \mathrm{H}$, Chen M, Forrester JV. Para-inflammation in the aging retina. Prog Retin Eye Res. 2009;28(5):348-68.

5. Herrero-Vanrell R, Bravo-Osuna I, Andres-Guerrero V, Vicario-de-la-Torre M, Molina-Martinez IT. The potential of using biodegradable microspheres in retinal diseases and other intraocular pathologies. Prog Retin Eye Res. 2014;42:27-43.

6. Rowe-Rendleman CL, Durazo SA, Kompella UB, Rittenhouse KD, Di Polo A, Weiner AL, et al. Drug and gene delivery to the back of the eye: from bench to bedside. Invest Ophthalmol Vis Sci. 2014;55(4):2714-30.

7. Hussain RM, Ciulla TA. Treatment strategies for refractory diabetic macular edema: switching anti-VEGF treatments, adopting corticosteroid-based treatments, and combination therapy. Expert Opin Biol Ther. 2016;16(3):365-74.

8. Bravo-Osuna I, Andres-Guerrero V, Pastoriza Abal P, Molina-Martinez IT, Herrero-Vanrell R. Pharmaceutical microscale and nanoscale approaches for efficient treatment of ocular diseases. Drug Deliv Transl Res. 2016;6(6):686-707.

9. Zulliger R, Conley SM, Naash MI. Non-viral therapeutic approaches to ocular diseases: An overview and future directions. J Control Release. 2015;219:471-87.

10. Solinis MA, del Pozo-Rodriguez A, Apaolaza PS, Rodriguez-Gascon A. Treatment of ocular disorders by gene therapy. Eur J Pharm Biopharm. 2015;95(Pt B):331-42.

11. Wong WL, Su X, Li X, Cheung CM, Klein R, Cheng CY, et al. Global prevalence of age-related macular degeneration and disease burden projection for 2020 and 2040: a systematic review and meta-analysis. Lancet Glob Health. 2014;2(2):e106-16.

12. Krishnan T, Ravindran RD, Murthy GV, Vashist P, Fitzpatrick KE, Thulasiraj RD, et al. Prevalence of early and late age-related macular degeneration in India: the INDEYE study. Invest Ophthalmol Vis Sci. 2010;51(2):701-7.

13. Lim LS, Mitchell P, Seddon JM, Holz FG, Wong TY. Age-related macular degeneration. Lancet. 2012;379(9827):1728-38.

14. Khan KN, Mahroo OA, Khan RS, Mohamed MD, McKibbin M, Bird A, et al. Differentiating drusen: Drusen and drusen-like appearances associated with ageing, age-related macular degeneration, inherited eye disease and other pathological processes. Prog Retin Eye Res. 2016;53:70-106. 
15. Gupta B, Jyothi S, Sivaprasad S. Current treatment options for retinal angiomatous proliferans (RAP). Br J Ophthalmol. 2010;94(6):672-7.

16. Participants VR. Guidelines for using verteporfin (Visudyne) in photodynamic therapy for choroidal neovascularization due to age-related macular degeneration and other causes: update. Retina. 2005;25(2):119-34.

17. Wormald R, Evans J, Smeeth L, Henshaw K. Photodynamic therapy for neovascular age-related macular degeneration. Cochrane Database Syst Rev. 2005(4):CD002030.

18. Grisanti S, Ziemssen F. Bevacizumab: Off-label use in ophthalmology. Indian Journal of Ophthalmology. 2007;55(6):4.

19. Gaudreault J, Fei D, Rusit J, Suboc P, Shiu V. Preclinical pharmacokinetics of Ranibizumab (rhuFabV2) after a single intravitreal administration. Invest Ophthalmol Vis Sci. 2005;46(2):726-33.

20. Kaiser PK. Antivascular endothelial growth factor agents and their development: therapeutic implications in ocular diseases. Am J Ophthalmol. 2006;142(4):660-8.

21. Brechner RJ, Rosenfeld PJ, Babish JD, Caplan S. Pharmacotherapy for neovascular age-related macular degeneration: an analysis of the $100 \% 2008$ medicare fee-for-service part B claims file. Am J Ophthalmol. 2011;151(5):887-95.e1.

22. Martin DF, Maguire MG, Ying GS, Grunwald JE, Fine SL, Jaffe GJ, et al. Ranibizumab and bevacizumab for neovascular age-related macular degeneration. $\mathrm{N}$ Engl J Med. 2011;364(20):1897-908.

23. Dixon JA, Oliver SC, Olson JL, Mandava N. VEGF Trap-Eye for the treatment of neovascular age-related macular degeneration. Expert Opin Investig Drugs. 2009;18(10):1573-80.

24. Do DV. Antiangiogenic approaches to age-related macular degeneration in the future. Ophthalmology. 2009;116(10 Suppl):S24-6.

25. Bourne RR, Stevens GA, White RA, Smith JL, Flaxman SR, Price H, et al. Causes of vision loss worldwide, 1990-2010: a systematic analysis. Lancet Glob Health. 2013;1(6):e339-49.

26. Yau JW, Rogers SL, Kawasaki R, Lamoureux EL, Kowalski JW, Bek T, et al. Global prevalence and major risk factors of diabetic retinopathy. Diabetes Care. 2012;35(3):556-64.

27. Liew $\mathrm{G}$, Klein R, Wong TY. The role of genetics in susceptibility to diabetic retinopathy. Int Ophthalmol Clin. 2009;49(2):35-52.

28. Abhary S, Hewitt AW, Burdon KP, Craig JE. A systematic meta-analysis of genetic association studies for diabetic retinopathy. Diabetes. 2009;58(9):2137-47.

29. Clustering of long-term complications in families with diabetes in the diabetes control and complications trial. The Diabetes Control and Complications Trial Research Group. Diabetes. 1997;46(11):1829-39.

30. Kern TS. Contributions of inflammatory processes to the development of the early stages of diabetic retinopathy. Exp Diabetes Res. 2007;2007:95103. 
31. Nunes S, Pires I, Rosa A, Duarte L, Bernardes R, Cunha-Vaz J. Microaneurysm turnover is a biomarker for diabetic retinopathy progression to clinically significant macular edema: findings for type 2 diabetics with nonproliferative retinopathy. Ophthalmologica. 2009;223(5):292-7.

32. De Venecia G, Davis M, Engerman R. Clinicopathologic correlations in diabetic retinopathy. I. Histology and fluorescein angiography of microaneurysms. Arch Ophthalmol. 1976;94(10):1766-73.

33. Kohner EM, Henkind P. Correlation of fluorescein angiogram and retinal digest in diabetic retinopathy. Am J Ophthalmol. 1970;69(3):403-14.

34. Tang J, Kern TS. Inflammation in diabetic retinopathy. Prog Retin Eye Res. $2011 ; 30(5): 343-58$.

35. The effect of intensive treatment of diabetes on the development and progression of long-term complications in insulin-dependent diabetes mellitus. The Diabetes Control and Complications Trial Research Group. N Engl J Med. 1993;329(14):977-86.

36. Tight blood pressure control and risk of macrovascular and microvascular complications in type 2 diabetes: UKPDS 38. UK Prospective Diabetes Study Group. BMJ. 1998;317(7160):703-13.

37. Mauer M, Zinman B, Gardiner R, Suissa S, Sinaiko A, Strand T, et al. Renal and retinal effects of enalapril and losartan in type 1 diabetes. N Engl $\mathrm{J}$ Med.

2009;361(1):40-51.

38. Mancia G. Effects of intensive blood pressure control in the management of patients with type 2 diabetes mellitus in the Action to Control Cardiovascular Risk in Diabetes (ACCORD) trial. Circulation. 2010;122(8):847-9.

39. Rami HE, Barham R, Sun JK, Silva PS. Evidence-Based Treatment of Diabetic Retinopathy. Semin Ophthalmol. 2016:1-8.

40. Dhoot DS, Avery RL. Vascular Endothelial Growth Factor Inhibitors for Diabetic Retinopathy. Curr Diab Rep. 2016;16(12):122.

41. Stewart MW. Treatment of diabetic retinopathy: Recent advances and unresolved challenges. World J Diabetes. 2016;7(16):333-41.

42. Cheung N, Mitchell $P$, Wong TY. Diabetic retinopathy. Lancet. 2010;376(9735):124-36.

43. Ferrari S, Di lorio E, Barbaro V, Ponzin D, Sorrentino FS, Parmeggiani F. Retinitis pigmentosa: genes and disease mechanisms. Curr Genomics. 2011;12(4):238-49.

44. Hartong DT, Berson EL, Dryja TP. Retinitis pigmentosa. Lancet. 2006;368(9549):1795-809.

45. Bainbridge JW, Mehat MS, Sundaram V, Robbie SJ, Barker SE, Ripamonti C, et al. Long-term effect of gene therapy on Leber's congenital amaurosis. N Engl J Med. 2015;372(20):1887-97. 
46. Maguire AM, Simonelli F, Pierce EA, Pugh EN, Mingozzi F, Bennicelli J, et al. Safety and efficacy of gene transfer for Leber's congenital amaurosis. N Engl J Med. 2008;358(21):2240-8.

47. Winter JO, Cogan SF, Rizzo JF. Retinal prostheses: current challenges and future outlook. Journal of Biomaterials Science, Polymer Edition. 2007;18(8):1031-55.

48. Stingl K, Zrenner E. Electronic approaches to restitute vision in patients with neurodegenerative diseases of the retina. Ophthalmic Res. 2013;50(4):215-20.

49. Guadagni V, Novelli E, Piano I, Gargini C, Strettoi E. Pharmacological approaches to retinitis pigmentosa: A laboratory perspective. Prog Retin Eye Res. 2015;48:62-81.

50. Quigley HA, Broman AT. The number of people with glaucoma worldwide in 2010 and 2020. Br J Ophthalmol. 2006;90(3):262-7.

51. European Glaucoma Society. Terminology and guidelines for glaucoma. 4th ed. EGS, editor. Italy: PubliComm; 2014. 197 p.

52. Kass MA, Heuer DK, Higginbotham EJ, Johnson CA, Keltner JL, Miller JP, et al. The Ocular Hypertension Treatment Study: a randomized trial determines that topical ocular hypotensive medication delays or prevents the onset of primary open-angle glaucoma. Arch Ophthalmol. 2002;120(6):701-13; discussion 829-30.

53. Medeiros FA, Weinreb RN, Zangwill LM, Alencar LM, Sample PA, Vasile C, et al. Long-term intraocular pressure fluctuations and risk of conversion from ocular hypertension to glaucoma. Ophthalmology. 2008;115(6):934-40.

54. Musch DC, Gillespie BW, Niziol LM, Lichter PR, Varma R, Group CS. Intraocular pressure control and long-term visual field loss in the Collaborative Initial Glaucoma Treatment Study. Ophthalmology. 2011;118(9):1766-73.

55. Davis BM, Crawley L, Pahlitzsch M, Javaid F, Cordeiro MF. Glaucoma: the retina and beyond. Acta Neuropathol. 2016;132(6):807-26.

56. Cordeiro MF, Migdal C, Bloom P, Fitzke FW, Moss SE. Imaging apoptosis in the eye. Eye (Lond). 2011;25(5):545-53.

57. Anderson DR, Hendrickson A. Effect of intraocular pressure on rapid axoplasmic transport in monkey optic nerve. Invest Ophthalmol. 1974;13(10):771-83.

58. Almasieh M, Wilson AM, Morquette B, Cueva Vargas JL, Di Polo A. The molecular basis of retinal ganglion cell death in glaucoma. Prog Retin Eye Res. 2012;31(2):152-81.

59. Calkins DJ. Critical pathogenic events underlying progression of neurodegeneration in glaucoma. Prog Retin Eye Res. 2012;31(6):702-19.

60. Osborne NN. Mitochondria: Their role in ganglion cell death and survival in primary open angle glaucoma. Exp Eye Res. 2010;90(6):750-7.

61. Vecino E, Rodriguez FD, Ruzafa N, Pereiro X, Sharma SC. Glia-neuron interactions in the mammalian retina. Prog Retin Eye Res. 2016;51:1-40. 
62. Urtti A. Challenges and obstacles of ocular pharmacokinetics and drug delivery. Adv Drug Deliv Rev. 2006;58(11):1131-5.

63. Ramazani F, Chen W, van Nostrum CF, Storm G, Kiessling F, Lammers T, et al. Strategies for encapsulation of small hydrophilic and amphiphilic drugs in PLGA microspheres: State-of-the-art and challenges. Int J Pharm. 2016;499(1-2):358-67.

64. Del Amo EM, Urtti A. Current and future ophthalmic drug delivery systems. A shift to the posterior segment. Drug Discov Today. 2008;13(3-4):135-43.

65. Klein R, Klein BE. The prevalence of age-related eye diseases and visual impairment in aging: current estimates. Invest Ophthalmol Vis Sci.

2013;54(14):ORSF5-ORSF13.

66. Mansoor S, Kuppermann BD, Kenney MC. Intraocular sustained-release delivery systems for triamcinolone acetonide. Pharm Res. 2009;26(4):770-84.

67. Kwak HW, D'Amico DJ. Evaluation of the retinal toxicity and pharmacokinetics of dexamethasone after intravitreal injection. Arch Ophthalmol. 1992;110(2):259-66.

68. Hou H, Wang C, Nan K, Freeman WR, Sailor MJ, Cheng L. Controlled Release of Dexamethasone From an Intravitreal Delivery System Using Porous Silicon Dioxide. Invest Ophthalmol Vis Sci. 2016;57(2):557-66.

69. Andrés-Guerrero V, Zong M, Ramsay E, Rojas B, Sarkhel S, Gallego B, et al. Novel biodegradable polyesteramide microspheres for controlled drug delivery in Ophthalmology. J Control Release. 2015;211:105-17.

70. Cáceres-del-Carpio J, Costa RD, Haider A, Narayanan R, Kuppermann BD. Corticosteroids: Triamcinolone, Dexamethasone and Fluocinolone. Dev Ophthalmol. 2016;55:221-31.

71. Cardillo JA, Souza-Filho AA, Oliveira AG. Intravitreal Bioerudivel sustainedrelease triamcinolone microspheres system (RETAAC). Preliminary report of its potential usefulnes for the treatment of diabetic macular edema. Arch Soc Esp Oftalmol. 2006;81(12):675-7, 9-81.

72. Blatsios G, Tzimas AS, Mattheolabakis G, Panagi Z, Avgoustakis K, Gartaganis SP. Development of biodegradable controlled release scleral systems of triamcinolone acetonide. Curr Eye Res. 2010;35(10):916-24.

73. Kadam RS, Tyagi P, Edelhauser HF, Kompella UB. Influence of choroidal neovascularization and biodegradable polymeric particle size on transscleral sustained delivery of triamcinolone acetonide. Int J Pharm. 2012;434(1-2):140-7.

74. Zarei-Ghanavati S, Malaekeh-Nikouei B, Pourmazar R, Seyedi S. Preparation, characterization, and in vivo evaluation of triamcinolone acetonide microspheres after intravitreal administration. J Ocul Pharmacol Ther. 2012;28(5):502-6.

75. Bandi N, Kompella UB. Budesonide reduces vascular endothelial growth factor secretion and expression in airway (Calu-1) and alveolar (A549) epithelial cells. Eur J Pharmacol. 2001;425(2):109-16.

76. Kompella UB, Bandi N, Ayalasomayajula SP. Subconjunctival nano- and microparticles sustain retinal delivery of budesonide, a corticosteroid capable of inhibiting VEGF expression. Invest Ophthalmol Vis Sci. 2003;44(3):1192-201. 
77. Ayalasomayajula SP, Amrite AC, Kompella UB. Inhibition of cyclooxygenase-2, but not cyclooxygenase-1, reduces prostaglandin E2 secretion from diabetic rat retinas. Eur J Pharmacol. 2004;498(1-3):275-8.

78. Saishin Y, Takahashi K, Melia M, Vinores SA, Campochiaro PA. Inhibition of protein kinase $\mathrm{C}$ decreases prostaglandin-induced breakdown of the blood-retinal barrier. J Cell Physiol. 2003;195(2):210-9.

79. Derevjanik NL, Vinores SA, Xiao WH, Mori K, Turon T, Hudish T, et al. Quantitative assessment of the integrity of the blood-retinal barrier in mice. Invest Ophthalmol Vis Sci. 2002;43(7):2462-7.

80. Ayalasomayajula SP, Kompella UB. Celecoxib, a selective cyclooxygenase-2 inhibitor, inhibits retinal vascular endothelial growth factor expression and vascular leakage in a streptozotocin-induced diabetic rat model. Eur $\mathrm{J}$ Pharmacol. 2003;458(3):283-9.

81. Kammerl MC, Debler J, Riegger GA, Krämer BK. COX-2 inhibitors and risk of heart failure. Lancet. 2004;364(9444):1486-7; author reply 7.

82. Amrite AC, Ayalasomayajula SP, Cheruvu NP, Kompella UB. Single periocular injection of celecoxib-PLGA microparticles inhibits diabetes-induced elevations in retinal PGE2, VEGF, and vascular leakage. Invest Ophthalmol Vis Sci. 2006;47(3):1149-60.

83. Nadal-Nicolás FM, Rodriguez-Villagra E, Bravo-Osuna I, Sobrado-Calvo P, Molina-Martínez I, Villegas-Pérez MP, et al. Ketorolac Administration Attenuates Retinal Ganglion Cell Death After Axonal Injury. Invest Ophthalmol Vis Sci. 2016;57(3):1183-92.

84. Van Gelder RN. Photochemical approaches to vision restoration. Vision Res. 2015;111(Pt B):134-41.

85. Groynom R, Shoffstall E, Wu LS, Kramer RH, Lavik EB. Controlled release of photoswitch drugs by degradable polymer microspheres. J Drug Target. 2015;23(78):710-5.

86. Sinha VR, Trehan A. Biodegradable microspheres for protein delivery. J Control Release. 2003;90(3):261-80.

87. Bilati U, Allemann E, Doelker E. Strategic approaches for overcoming peptide and protein instability within biodegradable nano- and microparticles. Eur J Pharm Biopharm. 2005;59(3):375-88.

88. van de Weert M, Hennink WE, Jiskoot W. Protein instability in poly(lactic-coglycolic acid) microparticles. Pharm Res. 2000;17(10):1159-67.

89. Al Haushey L, Bolzinger MA, Bordes C, Gauvrit JY, Briancon S. Improvement of a bovine serum albumin microencapsulation process by screening design. Int $\mathrm{J}$ Pharm. 2007;344(1-2):16-25.

90. Blanco D, Alonso MJ. Protein encapsulation and release from poly(lactidecoglycolide) microspheres: effect of the protein and polymer properties and of the coencapsulation of surfactant. Eur J Pharm Biopharm. 1998;45. 
91. Garbayo E, Ansorena E, Lanciaego JL, Aymerich MS, Blanco-Prieto MJ. Sustained release of bioactive glycosylated glial cell-line derived neurotrophic factor from biodegradable polymeric microspheres. Eur J Pharm Biopharm. 2008;69.

92. Garbayo E, Montero-Menei CN, Ansorena E, Lanciego JL, Aymerich MS, Blanco-Prieto MJ. Effective GDNF brain delivery using microspheres a promising strategy for Parkinson's disease. J Control Release. 2009;135.

93. Tobío M, Nolley J, Guo Y, Mclver J, Alonso MJ. A novel system based on a poloxamer PLGA blend as a tetanus toxoid delivery vehicle. Pharm Res. 1999;16.

94. Leach WT, Simpson DT, Val TN, Anuta EC, Yu ZS, Williams RO, et al. Uniform encapsulation of stable protein nanoparticles produced by spray freezing for the reduction of burst release. J Pharm Sci. 2005;94.

95. Yuan W, Wu F, Guo M, Jin T. Development of protein delivery microsphere system by a novel S/O/O/W multi-emulsion. Eur J Pharm Sci. 2009;36.

96. Han $\mathrm{Y}$, Tian H, He $\mathrm{P}$, Chen $\mathrm{X}$, Jing $\mathrm{X}$. Insulin nanoparticles preparation and encapsulation into poly(lactic-co-glycolic acid) microspheres by using an anhydrous system. Int J Pharm. 2009;378.

97. Morita T, Sakamura Y, Horikiri Y, Suzuki T, Yoshino H. Protein encapsulation into biodegradable microspheres by a novel S/O/W emulsion method using poly (ethylene glycol) as a protein micronization adjuvant. J Control Release. 2000;69.

98. Koennings S, Sapin A, Blunk T, Menei P, Goepferich A. Towards controlled release of BDNF manufacturing strategies for protein-loaded lipid implants and biocompatibility evaluation in the brain. J Control Release. 2007;119.

99. Yandrapu SK, Upadhyay AK, Petrash JM, Kompella UB. Nanoparticles in porous microparticles prepared by supercritical infusion and pressure quench technology for sustained delivery of bevacizumab. Mol Pharm. 2013;10(12):4676-86.

100. Li F, Hurley B, Liu Y, Leonard B, Griffith M. Controlled release of bevacizumab through nanospheres for extended treatment of age-related macular degeneration. Open Ophthalmol J. 2012;6:54-8.

101. Elsaid N, Jackson TL, Elsaid Z, Alqathama A, Somavarapu S. PLGA Microparticles Entrapping Chitosan-Based Nanoparticles for the Ocular Delivery of Ranibizumab. Mol Pharm. 2016;13(9):2923-40.

102. Moreno MR, Tabitha TS, Nirmal J, Radhakrishnan K, Yee CH, Lim S, et al. Study of stability and biophysical characterization of ranibizumab and aflibercept. Eur $\mathrm{J}$ Pharm Biopharm. 2016;108:156-67.

103. Ye Z, Ji YL, Ma X, Wen JG, Wei W, Huang SM. Pharmacokinetics and distributions of bevacizumab by intravitreal injection of bevacizumab-PLGA microspheres in rabbits. Int J Ophthalmol. 2015;8(4):653-8.

104. Zhang L, Si T, Fischer AJ, Letson A, Yuan S, Roberts CJ, et al. Coaxial Electrospray of Ranibizumab-Loaded Microparticles for Sustained Release of AntiVEGF Therapies. PLoS One. 2015;10(8):e0135608.

105. Thanos C, Emerich D. Delivery of neurotrophic factors and therapeutic proteins for retinal diseases. Expert Opin Biol Ther. 2005;5(11):1443-52. 
106. Lin LF, Doherty DH, Lile JD, Bektesh S, Collins F. GDNF: a glial cell linederived neurotrophic factor for midbrain dopaminergic neurons. Science.

1993;260(5111):1130-2.

107. Chen ZY, He ZY, He C, Lu CL, Wu XF. Human glial cell-line-derived neurotrophic factor: a structure-function analysis. Biochem Biophys Res Commun. 2000;268(3):692-6.

108. Bohn MC, Kozlowski DA, Connor B. Glial cell line-derived neurotrophic factor (GDNF) as a defensive molecule for neurodegenerative disease: a tribute to the studies of antonia vernadakis on neuronal-glial interactions. Int J Dev Neurosci. 2000;18(7):679-84.

109. Baltmr A, Duggan J, Nizari S, Salt TE, Cordeiro MF. Neuroprotection in glaucoma - Is there a future role? Exp Eye Res. 2010;91(5):554-66.

110. Walton KM. GDNF: a novel factor with therapeutic potential for neurodegenerative disorders. Mol Neurobiol. 1999;19(1):43-59.

111. Campos C, Rocha NB, Lattari E, Paes F, Nardi AE, Machado S. Exerciseinduced neuroprotective effects on neurodegenerative diseases: the key role of trophic factors. Expert Rev Neurother. 2016;16(6):723-34.

112. Sullivan AM, O'Keeffe GW. Neurotrophic factor therapy for Parkinson's disease: past, present and future. Neural Regen Res. 2016;11(2):205-7.

113. Budni J, Bellettini-Santos T, Mina F, Garcez ML, Zugno Al. The involvement of BDNF, NGF and GDNF in aging and Alzheimer's disease. Aging Dis. 2015;6(5):33141.

114. Read SP, Cashman SM, Kumar-Singh R. POD nanoparticles expressing GDNF provide structural and functional rescue of light-induced retinal degeneration in an adult mouse. Mol Ther. 2010;18(11):1917-26.

115. Yang PB, Seiler MJ, Aramant RB, Yan F, Mahoney MJ, Kitzes LM, et al. Trophic factors GDNF and BDNF improve function of retinal sheet transplants. Exp Eye Res. 2010;91(5):727-38.

116. Checa-Casalengua P, Jiang C, Bravo-Osuna I, Tucker BA, Molina-Martinez IT, Young MJ, et al. Retinal ganglion cells survival in a glaucoma model by GDNF/Vit $E$ PLGA microspheres prepared according to a novel microencapsulation procedure. $J$ Control Release. 2011;156(1):92-100.

117. Osanai M, Nishikiori N, Lee GH, Sawada N. Emerging novel treatment strategies for diabetic eye diseases. Curr Diabetes Rev. 2010;6(1):35-41.

118. Frasson M, Picaud S, Leveillard T, Simonutti M, Mohand-Said S, Dreyfus H, et al. Glial cell line-derived neurotrophic factor induces histologic and functional protection of rod photoreceptors in the rd/rd mouse. Invest Ophthalmol Vis Sci. 1999;40(11):272434.

119. Koeberle PD, Ball AK. Effects of GDNF on retinal ganglion cell survival following axotomy. Vision Res. 1998;38(10):1505-15.

120. Yan Q, Wang J, Matheson CR, Urich JL. Glial cell line-derived neurotrophic factor (GDNF) promotes the survival of axotomized retinal ganglion cells in adult rats: 
comparison to and combination with brain-derived neurotrophic factor (BDNF). J Neurobiol. 1999;38(3):382-90.

121. Kyhn MV, Klassen H, Johansson UE, Warfvinge K, Lavik E, Kiilgaard JF, et al. Delayed administration of glial cell line-derived neurotrophic factor (GDNF) protects retinal ganglion cells in a pig model of acute retinal ischemia. Exp Eye Res.

2009;89(6):1012-20.

122. Andrieu-Soler C, Aubert-Pouessel A, Doat M, Picaud S, Halhal M, Simonutti M, et al. Intravitreous injection of PLGA microspheres encapsulating GDNF promotes the survival of photoreceptors in the rd1/rd1 mouse. Mol Vis. 2005;11:1002-11.

123. Ward MS, Khoobehi A, Lavik EB, Langer R, Young MJ. Neuroprotection of retinal ganglion cells in DBA/2J mice with GDNF-loaded biodegradable microspheres. J Pharm Sci-Us. 2007;96(3):558-68.

124. Jiang C, Moore MJ, Zhang X, Klassen H, Langer R, Young M. Intravitreal injections of GDNF-loaded biodegradable microspheres are neuroprotective in a rat model of glaucoma. Mol Vis. 2007;13:1783-92.

125. Checa-Casalengua P, Jiang C, Bravo-Osuna I, Tucker BA, Molina-Martinez IT, Young MJ, et al. Preservation of biological activity of glial cell line-derived neurotrophic factor (GDNF) after microencapsulation and sterilization by gamma irradiation. Int $\mathrm{J}$ Pharm. 2012;436(1-2):545-54.

126. Yao J, Tucker BA, Zhang X, Checa-Casalengua P, Herrero-Vanrell R, Young MJ. Robust cell integration from co-transplantation of biodegradable MMP2-PLGA microspheres with retinal progenitor cells. Biomaterials. 2011;32(4):1041-50.

127. Marti HH. Erythropoietin and the hypoxic brain. J Exp Biol. 2004;207(Pt 18):3233-42.

128. Rong X, Mo X, Ren T, Yang S, Yuan W, Dong J, et al. Neuroprotective effect of erythropoietin-loaded composite microspheres on retinal ganglion cells in rats. Eur $\mathrm{J}$ Pharm Sci. 2011;43(4):334-42.

129. Wang Y, Zhang H, Liu Y, Li P, Cao Z, Cao Y. Erythropoietin (EPO) protects against high glucose-induced apoptosis in retinal ganglional cells. Cell Biochem Biophys. 2015;71(2):749-55.

130. Rong X, Yang S, Miao H, Guo T, Wang Z, Shi W, et al. Effects of erythropoietindextran microparticle-based PLGA/PLA microspheres on RGCs. Invest Ophthalmol Vis Sci. 2012;53(10):6025-34.

131. Rong X, Yuan W, Lu Y, Mo X. Safety evaluation of poly(lactic-co-glycolic acid)/poly(lactic-acid) microspheres through intravitreal injection in rabbits. Int $J$ Nanomedicine. 2014;9:3057-68.

132. Shmueli RB, Ohnaka M, Miki A, Pandey NB, Lima e Silva R, Koskimaki JE, et al. Long-term suppression of ocular neovascularization by intraocular injection of biodegradable polymeric particles containing a serpin-derived peptide. Biomaterials. 2013;34(30):7544-51.

133. Chen YS, Green CR, Wang K, Danesh-Meyer HV, Rupenthal ID. Sustained intravitreal delivery of connexin43 mimetic peptide by poly(D,L-lactide-co-glycolide) 
acid micro- and nanoparticles--Closing the gap in retinal ischaemia. Eur $\mathrm{J}$ Pharm Biopharm. 2015;95(Pt B):378-86.

134. Isiegas C, Marinich-Madzarevich JA, Marchena M, Ruiz JM, Cano MJ, de la Villa $P$, et al. Intravitreal Injection of Proinsulin-Loaded Microspheres Delays Photoreceptor Cell Death and Vision Loss in the rd10 Mouse Model of Retinitis Pigmentosa. Invest Ophthalmol Vis Sci. 2016;57(8):3610-8.

135. Corrochano S, Barhoum R, Boya P, Arroba Al, Rodriguez-Muela N, GomezVicente $\mathrm{V}$, et al. Attenuation of vision loss and delay in apoptosis of photoreceptors induced by proinsulin in a mouse model of retinitis pigmentosa. Invest Ophthalmol Vis Sci. 2008;49(9):4188-94.

136. Punzo C, Kornacker K, Cepko CL. Stimulation of the insulin/mTOR pathway delays cone death in a mouse model of retinitis pigmentosa. Nat Neurosci. 2009;12(1):44-52.

137. Gargini C, Terzibasi E, Mazzoni F, Strettoi E. Retinal organization in the retinal degeneration 10 (rd10) mutant mouse: a morphological and ERG study. J Comp Neurol. 2007;500(2):222-38.

138. Kimura H, Spee C, Sakamoto T, Hinton DR, Ogura Y, Tabata Y, et al. Cellular response in subretinal neovascularization induced by bFGF-impregnated microspheres. Invest Ophthalmol Vis Sci. 1999;40(2):524-8.

139. Cleland JL, Duenas ET, Park A, Daugherty A, Kahn J, Kowalski J, et al. Development of poly-(D,L-lactide--coglycolide) microsphere formulations containing recombinant human vascular endothelial growth factor to promote local angiogenesis. J Control Release. 2001;72(1-3):13-24.

140. Agarwal A, Parriott J, Demirel S, Argo C, Sepah YJ, Do DV, et al. Nonbiological pharmacotherapies for the treatment of diabetic macular edema. Expert Opin Pharmacother. 2015;16(17):2625-35.

141. Villegas VM, Aranguren LA, Kovach JL, Schwartz SG, Flynn HW, Jr. Current advances in the treatment of neovascular age-related macular degeneration. Expert Opin Drug Deliv. 2017;14(2):273-82.

142. Rezar-Dreindl S, Eibenberger K, Buehl W, Georgopoulos M, Weigert G, Krall C, et al. Role of Additional Dexamethasone for the Management of Persistent or Recurrent Neovascular Age-Related Macular Degeneration under Ranibizumab Treatment. Retina. 2016.

143. Wygledowska-Promienska D, Piotrowska-Gwozdz A, Piotrowska-Seweryn A, Mazur-Piotrowska G. Combination of Aflibercept and Bromfenac Therapy in AgeRelated Macular Degeneration: A Pilot Study Aflibercept and Bromfenac in AMD. Med Sci Monit. 2015;21:3906-12.

144. Osswald CR, Kang-Mieler JJ. Controlled and Extended In Vitro Release of Bioactive Anti-Vascular Endothelial Growth Factors from a Microsphere-Hydrogel Drug Delivery System. Curr Eye Res. 2016;41(9):1216-22. 


\section{FIGURE LEGENDS}

Figure 1: Eye and retina elementary structure.

Figure 2: A) Example of typical release profiles of a hydrophobic small molecule (I) hydrophilic small molecule (II) and protein (III) release from PLGA microspheres. B) Schematic representation of PLGA microspheres degradation in release media.

Figure 3: Schematic representation of retinal alterations involved in age-related macular degeneration and example of patients' vision.

Figure 4: Schematic representation of retinal alterations involved in diabetic retinopathy and example of patients' vision.

Figure 5: Schematic representation of retinal alterations involved in retinitis pigmentosa and example of patients' vision.

Figure 6: Schematic representation of retinal alterations involved in glaucoma and example of patients' vision. 